\title{
KATEKISMUS HEIDELBERG: SALAH SATU MATERI PENDIDIKAN AGAMA KRISTEN (PAK) YANG HISTORIS DAN KONTEKSTUAL
}

\author{
Oleh: Dr. Abialtar, M.Th ${ }^{1}$
}

\begin{abstract}
Abstrak
Salah satu kekayaan gereja adalah dokumen-dokumen pengajaran iman Kristen lahir pada zaman dan konteks tertentu. Salah satu dokumen iman yang terkenal adalah Katekismus Heidelberg (1563). Ia lahir dari "konspirasi" atau kerjasama antara gereja dan politik, Gereja Calvinis dan penguasa Palatinat, Jerman pada masa itu.

Belum banyak teolog Kristen yang secara khusus membahas muatan teologi Katekismus Heidelberg ini dengan memperhatikan konteks di mana itu dirumuskan dan lahir. Penulis mengkaji teologi Katekismus Heidelberg yang dapat dikategorikan dokumen materi PAK baik di gereja maupun di sekolah, dengan melihat aspek sejarah dan juga mengkaji pembahasan para teolog mengenai makna Katekismus Heidelberg. Tentu saja tidak terlupakan kajian biblis dan pengaruh kebijakan politik konteks tertentu untuk menemukan landasan berpikir para perumus Katekismus ini.

Harapan penulis bahwa kajian ini akan mendorong para pelaku pengajaran PAK untuk melandaskan perumusan materi pengajaran mereka dengan inspirasi kuat Katekismus Heidelberg. Dengan demikian, materi PAK akan selalu kontekstual, menjawab kebutuhan konteks yang di dalamna dirumuskan dan lahir. Penulis menggunakan metode penelitian kualitatif dengan basis penelitian perpustakaan.
\end{abstract}

Frasa Kunci: Katekismus Heidelberg, PAK, Calvinis, sejarah, teolog, teologi, kontekstual

\footnotetext{
${ }^{1}$ Dosen dan Ka. Prodi Teologi di STT Moriah Gading Serpong Tangerang Banten dan Pendeta GTM. Lulus Sarjana Teologi (S.Th) di STT Rantepao Tana Toraja tahun 1999. Lulus Magister Teologi (M.Th) di Theologische Universiteit Apeldoorn Belanda dan STT Jakarta tahun 2008. Melanjutkan studi Program Doktoral Teologi (D.Th) di STT Jakarta dan lulus tahun 2016.
} 


\section{Konteks Kelahiran Katekismus Heidelberg}

Calvinisme berkembang di wilayah Jerman melalui pengaruh pengungsipengungsi dari Perancis dan Belanda. Sejak tahun 40 abad XVII, lahirlah jemaat-jemaat pengungsi di daerahdaerah di mana penguasa setempat mengizinkannya antara lain di Emden, Wesel, dan kota-kota di Bremen. Daerah yang terbesar adalah Palatinat dengan ibukota Heidelberg, yang menjadi Reformiert pada tahun 1559. Dua orang pengikut Calvin dari Jerman Selatan yaitu Zacharias Ursinus dan Caspar Olevianus yang menjadi guru besar di Universitas Heidelberg. Merekalah penyusun Katekismus Heidelberg yang terkenal itu.

Katekismus Hedelberg disusun di provinsi Palatinat (Pfalz). Palatinat adalah salah satu daerah otonom di bagian barat kekaisaran Jerman, yang beribukota Heidelberg. Nama daerah ini di ambil dari bahasa Latin: Palatium yang berarti tempat tinggal seseorang yang berkedudukan tinggi. Pada masa sekarang ini daerah tersebut terletak di Neuburg, Zweibrucken, Simmern dan daerah-daerah lainnya. Kota Heidelberg adalah sebuah daerah perikanan, yang terletak di pesisir sungai Neckar. Di kota inilah pernah berdiri Gereja Santo Petrus (St. Paterskirche). Heidelberg berkembang menjadi kota dengan temboktembok dan menara-menaranya.

Pada abad ke XIII di Heidelberg telah berlaku peraturan-peraturan biarawan yang berasal dari ordo Agustinus. Mereka membawa kebudayaan-kebudayaan baru serta perkembangan ilmu pengetahuan. Pada tahun 1386 berdirilah sebuah universitas di Heidelberg dan oleh Raja Ruprecht III dan di bawah Raja Lodewijk III dibangunlah gereja yang kudus (Heiliggeistkirche) di sana. Penduduk kota Heidelberg waktu itu berjumlah kira-kira 4000 orang dan mereka kebanyakan sebagai petani, pengusaha anggur, dan nelayan.

Dari tahun 1476 sampai tahun 1508 (sebelum Reformasi) provinsi Palatinat diperintah oleh Raja Philip. Dia terkenal sebagai seorang Raja yang ramah dan menyenangkan. Di menginginkan Heidelberg menjadi kota kesenian. Di samping itu, Philip juga mengundang beberapa tokoh Humanisme seperti Rudolf Agricola untuk menyampaikan pidatonya di Heidelberg.

Pengganti Raja Philip adalah anak laki-lakinya, Lodewijk V dari tahun 1508 sampai tahun 1544. Dia terkenal sebagai raja yang selalu berhati-hati. Selama pemerintahannya telah mulai muncul angin reformasi gereja di beberapa tempat di Jerman. Dan hal itu terasa juga di Pfalz. Dalam keadaan seperti itu, Raja Lodewijk menempatkan diri dalam posisi netral. Di satu pihak dia menerima kunjungan pejabat-pejabat Gereja Katolik Roma tetapi di pihak lain toleran dengan pemikiran-pemikiran gerakan Reformasi. Bahkan dia memberikan tempat yang khusus bagi Reformasi Gereja di daerah Zweilbrucken.

Ketika Lodewijk V wafat pada tahun 1544, maka saudaranya Friedrich II menggantikan dia dan memerintah sampai tahun 1556. Salah satu kegemaran Friedrich II adalah melakukan perjalanan. Dia pernah mengunjungi Belanda, Spanyol dan Perancis. Pada tahun 1530, ketika menghadiri pertemuan parlemen di Augsburg, dia menerima pandanganpandangan penganut ajaran Luther dan dia tiba pada kesaksian bahwa mereka tidak boleh menghukum mereka yang 
dianggap bidat. ${ }^{2}$ Pada tanggal 3 Januari 1546, dia memperbolehkan untuk pertama kalinya ibadah gereja Protestan diadakan di Heidelberg. Walaupun demikian, Raja Lodewijk tidak pernah tiba pada keputusan untuk menjadi pengikut gerakan Protestan. Ia tetap sebagai penganut Gereja Katolik Roma.

Penguasa berikutnya setelah Raja Friedrich II wafat adalah Raja OttoHendrik. Dia adalah keponakan Raja Friedrich dan mulai memerintah pada tahun 1556 dan wafat pada tahun 1559 . Dia adalah teman Melanchthon dan telah banyak berpengaruh dalam pelayanan kegerejaan pada zamannya. Gerakan penting yang di lakukan oleh OttoHendrik adalah menggunakan Konfesi Augsburg sebagai pengakuan iman di daerah Palatinat tahun 1530. Semua pendeta dan pejabat gereja lainnya harus menjalankan atau memakai pengakuan iman itu. ${ }^{3}$ Kebijakan Otto Hendrik tersebut di atas adalah suatu kemajuan besar dari peran penguasa dalam gerakan Reformasi gereja waktu itu.

Akhirnya tibalah masa pemerintahan Raja Friedrich III tahun 1559 yang lahir pada tanggal 14 Februari 1555 di daerah kekuasaan Simmeren sebagai putra dari bagsawan Johan II. ${ }^{4}$ Pada tahun 1537, ia menikah dengan Maria, putri penguasa perbatasan yang bernama Kasimir von Branderburg-Kulmbach. Maria adalah pengikut Luther dan Friedrich III mengikuti dia. Pada tahun 1559 ia menggantikan ayahnya sebagai Raja wilayah Palatinat dan ia memasukkan orang-orang Protestan ke dalam

\footnotetext{
2 W. Verboom "De Totstandkoming van de Heidelberg Cathecismus" dalam W. Van't Spijker, (ed.) Het troostboek van de Kerk-Over de Heidelbergse Catechismus (Houten: der Hertog, 2005), 20.

${ }^{3}$ Ibid.,51.

${ }^{4}$ Ibid.,52.
}

wilayahnya. Pada waktu itu-lah dia memegang peranan penting sebagai pendamai yang berani dari berbagai macam aliran yang berbeda yaitu antara Lutheran, pengikut Melanchthon dan Calvin. ${ }^{5}$ Ketika Friedrich III menjadi raja, pada mulanya dia tetap sebagai pengikut Lutheran dan dia disebut sebagai rohaniawan dan guru besar Lutheran. Tetapi kemudian terjadilah konflik yang besar di Heidelberg antara Heshusius yang menganut pikiran Melanchthon, yang kemudian menjadi penganut Lutheran dengan Klebitz, seorang diaken, yang dipengaruhi oleh pengakuan iman Calvinis. Setelah melalui debat teologi selama lima hari, pada tahun 1560 ia betul-betul sampai pada pendirian menjadi pengikut setia Gereja Calvinis. ${ }^{6}$

Kelahiran Katekismus Heidelberg tidak terlepas dari peran Raja Friedrich III yang telah menjadi penganut setia ajaran Calvinis. Friedrich-lah yang pertama-tama berinisiatif untuk menyusun Katekismus Baru di daerahnya pada waktu itu. Seperti diketahui bahwa sebelum Katekismus Heidelberg disusun, telah ada beberapa Katekismus di lingkungan gereja-gereja Protestan yaitu Katekismus Kecil dan Katekismus Besar dari Martin Luther (1529) yang kemudian dihimpun dalam kitab Konkrod yang diterbitkan pada tanggal 25 juni $1580,{ }^{7}$ Katekismus dari Brenz (1535), dan Katekismus Kecil dan Katekismus Besar Karangan Ursinus (1562).”Sejak Raja Friedrich III memerintah, telah berhembus "angin segar" keagamaan di wilayahnya. "Cuius region, eius religio" artinya "yang punya daerah, dari dialah

\footnotetext{
${ }^{5}$ Ibid.

${ }^{6}$ Ibid.,54.

${ }^{7}$ Jan S. Aritonang, Berbagai Aliran di Dalam dan di Sekitar Gereja (Jakarta: BPK Gunung Mulia cet. Ke-7 2005), 38 .
} 
agama atau kepercayaan (agama)". ${ }^{8}$ Dia terpanggil untuk membentuk rakyatnya dengan doktrin Calvinis yang kuat pada waktu itu. Peran politis penguasa kadangkala dipakai Tuhan dalam merumuskan pengajaran gereja-Nya.

Untuk stabilisasi pembaharuan gereja, Friedrich III sangat menganggap penting untuk menyusun sebuah katekismus baru sebagai pondasi kuat untuk melindungi diri sendiri serta rakyatnya dari kecenderungan gerakan-gerakan yang berbeda yang berkobar di manamana, ${ }^{9}$ misalnya dalam menghadapi gerakan Kontra Reformasi. Selain itu Friedrich III sangat menginginkan kesatuan gereja dan yang paling penting adalah menjaga wibawa dan kehormatan gereja. ${ }^{10}$ Ia pun menginginkan buku pelajaran yang paling baik untuk pelajaran agama bagi rakyatnya. ${ }^{11}$

Perselihan antara teolog-teolog Luther dan Calvinyang sudah terjadi sejak dulu menjadi salah satu motivasi Raja Feiedrich III untuk segera menyusun pokok-pokok ajaran yang dapat menggabungkan atau menyatuhkan kebijaksanaan Lutheranisme dan Calvinisme yang terbaik. ${ }^{12}$ Dari sini terlihat bagaimana situasi yang tidak stabil mendorong kreativitas para teolog kerjasama dengan penguasa setempat untuk suatu materi PAK yang kontekstual yang berisi pokokpokok ajaran sebagai pedoman beriman.

H. Alting dan para pengikutnya sependapat bahwa Raja Friedrich III pada 1563 memberi perintah kepada dua orang

\footnotetext{
${ }^{8}$ Ibid., 71 .

${ }^{9}$ Karl Barth, Learning Jesus Christ Through the Heidelberg Catechism (Grand Rapids: William Eerdmans Publising Company, 19964), 22.

${ }^{10}$ Ibid.

11 G.I. Williamson, the HeidelbergCatechism: A study Guide (New Jersey: P \& R Publishing, 1993), 1.

${ }^{12}$ Mark A. Noll, Confessions and Catechism of the Reformation (Leicester: Apollos, 1991), 134.
}

teolog yaitu Zacharias Ursinus dan Casper Olevianus untuk menyusun suatu buku pengajaran baru. Siapakah kedua teolog dimaksud? Zacharias Urisinus (1534-1583) adalah penduduk asli Breslau (sekarang Polandia). Ia telah memulai pendidikan teologinya pada Melanchton di Wittenberg. Tetapi secara pribadi dia juga belajar dengan Calvin. Raja Friedrich III menyebut dia Profesor Teologi. ${ }^{13}$ Dia mengajar dogma di Universitas Heidelberg dan mengepalai Fakultas Sapienz di mana penghotbahpenghotbah dilatih. ${ }^{14}$ Latar belakang pendidikan Urusinus juga sangat memengaruhi rumusan dari Katekismus Heidelberg. Ia tercatat dan dikenal sebagai murid yang baik, ketika dia belajar di Gymnasium Elizabeth di Breslau dimana Andreas Winkler sebagai rector. ${ }^{15}$ Di tempat yang sama dia menjadi murid Katekisasi pastor Ambrosius Moibanus yang pernah merumuskan katekismus untuk kalangan pribadinya. Katekismus Muibanus menekankan penghiburan Injil yang menjadi sumber yang datang menghiasi Katekismus Kecil Ursinus itu (1562), dan khususnya dalam Katekismus Heidelberg (1563). ${ }^{16}$

Caspar Poletianus (1536-1587) adalah anggota Gereja Calvinis Perancis yang telah belajar pada Calvin dan Beza. Tetapi kemungkinan dia pernah membaca buku Melanchthon. Ia lahir di kota Trier pada tanggal 10 Agustus 1563, tahun kematian Erasmus dan penerbitan edisi I Institutio Calvin. ${ }^{17}$ Selama enam tahun ia belajar iman Protestan di Perancis (15501556) ${ }^{18}$ dan pernah menjadi pendeta besar di Heidelberg serta sebagai pendeta

\footnotetext{
13 Ibid.

${ }^{14}$ Fred H. Klooster, The Heidelberg Catechism, 6.

${ }^{15}$ Ibid., 121.

${ }^{16} \mathrm{Ibid}$

${ }^{17}$ Ibid., 130 .

${ }^{18}$ Ibid., 133
} 
istana Raja Friedrich III. $^{19}$ Sebagai pendeta istana tentu loyalitasnya terhadap perintah raja sangat baik. Selain mengabdi kepada Raja dalam pemenuhan kebutuhan rohani istana, dia juga memberi pengaruh yang besar kepada keluarga istana. Pengaruh yang besar adalah ajaran Calvin yang selalu menjadi dasar Khotbah Olevianus membimbing Raja kepada keputusan menjadi pengikut dan pejuang Calvinis di wilayah kekuasaanya, ${ }^{20}$ walaupun selama pemerintahan Raja Friedrich III (17 tahun lamanya), istrinya dan para kerabatnya mencoba mempengaruhi dia untuk menganut iman Lutheran. ${ }^{21}$ Kedua teolog mudah itulah yang pertama-tama membuat rancangan Katekismus Heidelberg pada awal tahun $1563 .^{22}$

Katekismus Heidelberg disusun dengan berpedoman pada katekismuskatekismus lain yang sudah ada sebelumnya. Menurut Flooster ${ }^{23}$ ada tiga sumber utama Katekismus Heidelberg yaitu:

Pertama, Katekismus mula-mula atau awal yang terdiri dari pertanyaanpertanyaan untuk anak-anak dalam Katekismus Boheian Bretheren (1502), yaitu buku kecil atau brosur untuk pengantar pengajaran bagi anak-anak yang tidak di ketahui namanya (1585) dan brosur dialog oleh Baderlandau (1586).

${ }^{19}$ Ibid

${ }^{20}$ Dikutip dari ceramah-ceramah Prof. Dr. J.W. Maris, Dalam kuliah Symboliek pada Theologische Universiteit Apelldoorn, Nederland, 2005.

21 Fred A. Klooster, Our Only Comfort A Comphensive Commentary on The Heidelberg Catechism volume two (Grand Rapids, Michigan: Faith Alive Christian Resources, 2001), 858.

22 Th. Van den End, Enam Belas Dokumen DasarDokumen Dasar Calvinisme (Jakarta: BPK Gunung Mulia, cet. ke-4, 2000), 202.

${ }^{23}$ Fred A. Klooster, The Heidelberg Catechism Origin and History..., 173-174.
Kedua, Katekismus-Katekismus Luther yang terdiri dari: Karangan Philip Melanchthon: "Loci Communes" yang terdiri dari banyak edisi (1561), buku pedoman, Dasa Titah, doa Bapa Kami dan lain-lain (1585) serta ujian Ordinandorum yang di gunakan oleh Ursinus di Breslau. Karangan Jhon Brenz: Katekismus Kecil-Pertanyaanpertanyaan iman Kristen untuk anak-anak yang di gunakan di Heidelberg beberapa tahun (1528) dan katekismus Besar (1535). Karangan Martin Luther: Katekismus Kecil (1529) dan Katekismus Besar. Dua Katekismus Lutheran yang sangat penting dan masih digunakan sampai sekarang, dan Katekismuskatekismus Lutheran Yang lain: Pengajaran Katekisasi dalam Iman Kristen: Bagaimana anak-anak muda diajar dan dilatih, karangan Adrew Altahmer (1528) dan Katekismus Muibanus oleh Pastor Ursinus Breslau (1533).

Ketiga, Katekismus-katekismus Calvinis yang terdiri dari: Pekerjaanpekerjaan awal: lembaran Katekismus Strasbourg (1525) Katekismus Zurich oleh Leojut, pertanyaan-pertanyaan dan Jawaban-jawaban untuk pengajaran anakanak oleh J. Oecolampadius, yang terdiri dari 43 pertanyaan (1525) eksposisi ringkas Doa Bapa Kami (1520) sebuah ekposisi Pengakuan Iman Rasuli (1530) oleh Jhon Zwick Constand, pertanyaan dan jawaban-jawaban oleh Hans Gerhardt (1525), Pengajaran Kristen untuk Anakanak Muda oleh Konrad Sam Ulyn (1528). Katekismus-Katekismus Strasbourg: Capito (1527), Bucer (1534) dan Zell (1535, 1537). (c) Katekismuskatekismus Zurich yang terdiri dari: Leo Cud: Lembaran Katekismus Zurich (1525), Pengajaran Agama Kristen (1534, 1535), Sebuah Surat Rumusan Agama Kristen $(1538,1539)$, Henry Bullinger: 15 Khotbah (1549-1551), Katekismus untuk 
Orang Dewasa (1559). Katekismuskatekismus Jenewa yang terdiri dari: Jhon Calvin: pengajaran dalam iman (1537), Katekismus Jenewa $(1541,1545)$, dan Institusi Agama Kristen (1536-1559). Theodore Beza: Surat Pengakuan (1562). Emden-London Katekismus karangan a'Lasco: investigasi singkat mengenai iman (1553 (1531?), Katekismus singkat oleh Micronius (1552), Iktisar London (1553) dan Katekismus untuk Anak-anak oleh Pendeta-pendeta di Emden (1554), dan Katekismus-katekismus Ursinus (Heidelberg): Katekismus Mayor (Summa Theologiae, 323 pertanyaan (1561) dan Katekismus Minor, 108 pertanyaan.

Sumber-sumber rujukan perumus Katekismus Heidelberg ternyata lumayan banyak. Karena itu, dapat dikatakan bahwa Katekismus Heidelberg tergolong Katekismus Ekumenis walaupun penggagas dan perumusnya adalah teologteolog Gereja Calvinis. Salah satu bukti konkret bahwa sumber Katekismus Heidelberg terdiri dari Katekismuskatekismus yang bervariasi seperti yang di sebutkan di atas adalah kata "penghiburan" yang adalah kata umum pada Literatur Protestan; Injil dan pembenaran oleh iman dirasakan sebagai dasar penghiburan yang sejati. ${ }^{24}$

M.A Gooszen dalam bukunya In de Heidelbergsce Chatechismus: Textus Receptus Met Toelichtende Teksten $(1890)^{25}$ menetapkan hubunganhubungan Sembilan Katekismus dengan setiap pertanyaan Katekismus Heidelberg yaitu dua katekismus dari Leo Jud, satu katekismus dari Bulliger, Katekismus Jenewa dari Calvin, tiga katekismus dari Katekismus London-Emden oleh a'Lasco-Micronius, dan dua katekismus dari Katekismus Ursinus. Sedangkan A.

\footnotetext{
${ }^{24}$ Ibid., 177

25 Ibid.
}

Lang dalam "Der Hedelberger Katechismus und vier verwandte Katechismen (1907)" memperbandingkan Ketekismus Heidelberg dengan empat katekismus lain, yaitu dua Katekismus Ursinus dan Katekismus Leo Jud dan Micronius. ${ }^{26}$

Dapat disimpulkan bahwa isi Katekismus Heidelberg diwarnai oleh teologi-teologi yang bervariasi dari tokoh-tokoh Reformasi dan bukan hanya teologi Calvin yang terdapat di dalamnya. Secara singkat Klootser mengatakan, The Heidelberg Chatechism is actually 'a coat of many colors". ${ }^{27}$ Oleh karena itu, penyelidikan penuh Katekismus Heidelberg mengungkap banyak relasi-relasi struktural halus dengan pelbagai katekismus lainnya. $^{28}$

Rancangan dari Katekismus Heidelberg itu disahkan oleh Sinode Gereja daerah Pfalz (Sinode Heidelberg) tahun itu juga. Melalui sebuah pertemuan para pendeta dan teolog di Pfalz, ditegaskan persetujuan rancangan Katekismus Heidelberg, dengan cara membubuhi tandatangan atas naskah persetujuan. ${ }^{29}$ Tradisi pembumbuhan tanda tangan inilah yang kemudian di warisi oleh beberapa gereja-gereja Calvinis lainnya. Mereka mengharuskan para pejabat Gereja terutama calon-calon pendeta menyetujui Katekismus Heidelberg sebagai pedoman ajaran Kristen dan pengakuan iman warisan Calvin, dengan membubuhkan tanda tangan. ${ }^{30}$ Tradisi ini kemudian di-perbaharui oleh calon-calon pendeta di gereja-gereja tertentu dengan tidak diwajibkan membubuhkan tanda

\footnotetext{
${ }^{26}$ Ibid.

27 Ibid.

${ }^{28}$ Ibid., 179.

29 Gereformeerde Bijbelstiching, Heidelberg Chatechismus (Leerdam: GBS, 1996),11.

${ }^{30} \mathrm{~K}$. Buiten Huis, wawacara penulis, Apeldon Belanda 10 oktober 2006.
} 
tangan, tetapi wajib mengikuti ujian Katekismus Heidelberg. ${ }^{31}$

Edisi pertama dari Katekismus Heidelberg selesai pada bulan Januari atau Februari 1563. Dalam edisi pertama itu, tercantum kata pengantar dari Raja Friedrich III, tertanggal 19 januari 1563. Setelah kata pengantar dari Raja, diikuti oleh 128 pertanyaan dan jawabannya yang belum bernomor dan belum di bagi per-minggu.

Menarik, kata pengantar tertanggal 19 Januari 1563, yang di tulis oleh Raja Freidrich III antara lain memuat pernyataan bahwa Katekismus Heidelberg disusun atas saran yang datang dari Fakultas Teologi di Heidelberg, bekerja sama dengan semua pengawas (superintendent) dan pelayananpelayanan gereja yang sangat penting. ${ }^{32}$ Raja tidak menyebut nama Zacharias Ursinus dan Caspar Olevianus secara khusus sebagai teolog-teolog yang berperan penting dalam penyusunan Katekismus Heidelberg. Hal ini membuktikan bahwa Katekismus Heidelberg adalah milik seluruh penduduk provinsi Palatinat, khususnya dan Gereja-gereja Calvinis pada umumnya. Selain itu, menurut hemat penulis merupakan Strategi Raja Friedrich III untuk menanamkan kebersamaan di daerah kekuasaannya.

31 Tradisi ini pernah terapkan juga di Gereja Toraja Mamasa (GTM). Calon pendeta yang sudah menyelesaikan pendidikan Teologi di sekolah tinggi teologi tertentu yang di akui oleh GTM, harus mengikuti ujian. Vikaris yang di laksanakan di kantor Sinode. Salah satu bahan ujian adalah Katekismus Heidelberg yang wajib di ikuti oleh setiap calon Pendeta.

32 C. Th. Boerke, "De mensen achter de Heidelbergse Catechismus" dalam W.

van't Spijker (ed.),Het troostboek van de KerkOver...,82. Lihat juga Fred H. Flooster,Our Only Comfort..., 151.
Beberapa minggu setelah edisi pertama Katekismus Heidelberg dikerjakan, menyusul edisi II, yang memuat 129 pertanyaan. Jadi, hanya bertambah satu pertanyaan saja. Dalam edisi II itu, pada pertanyaan no. 80 telah disisipkan perbedaan antara Perjamuan Malam Tuhan dengan Misa Paus. Di dalamnya disisipkan pertanyaan yang mengagap Misa sebagai "penyembah berhala yang terkutuk" (eine vermaledeite Abgotterei). Dalam edisi III terdapat kata-kata tajam menolak ajaran transsubstansiasi, yang telah dijadikan ajaran resmi Gereja Katolik Roma pada Tahun 1215 dan yang ditegaskan lagi oleh Konsili Trente pada tahun 1562, disertai ucapan kutuk atas semua orang yang menganut pandangan Protestan. Sementara itu, edisi IV Katekismus Heidelberg tahun 1563, telah dicamtumkan dalam Tata Gereja (bah. Belanda: kerkorde) Pfalz. Tata Gereja, yang dari Caspar Elvianus itu, berbicara mengenai Khotbah, Babtisan, Perjamuan Kudus, Tertib Gereja dan seterusnya. Di dalamnya di camtumkan antara lain peraturan untuk memperhatikan bahwa setiap hari minggu dan hari-hari Raya, satu bagian dari Katekismus Heidelberg harus di bacakan. Pada edisi IV itulah Katekismus Heidelberg dibagi kedalam limah puluh dua (52) minggu. Selain itu, tata Gereja memerintahkan bahwa setiap hari minggu pada kebaktian sore, yang dikhotbahkan (bahan utama khotbah) adalah mengenai Katekismus Heidelberg. ${ }^{33}$ Edisi IV itu di anggap sebagai teks final Katekismus Heidelberg.

Proses tersebarnya Katekismus ke daerah-daerah luar Jerman adalah melalui orang-orang Calvinis yang pada waktu itu mengungsi ke daerah-daerah lain karena mengalami penganiayaan. Mereka yang

${ }^{33}$ Bijbelstiching, Heidelberg,.. 12. 
berasal dari negeri Belanda banyak yang mengungsi ke Pfalz. Di sana mereka di lindungi oleh Raja setempat. Pada tahun 1563 telah ada terjemahan Katekismus Heidelberg edisi II dalam bahasa Belanda oleh seorang pengungsi, Gilles van der Erven dari Emden tetapi terjemahan ini masih sangat sederhana. ${ }^{34}$

Pada tahun 1566 Petrus Datheen berhasil menerjemahkan edisi III Katekismus Heidelberg bersama dengan penerbitan Nyanyian Mazmur edisi gubahan lama (Psalm van de oude berijming ) yang sampai sekarang masih dipakai oleh beberapa Gereja-gereja Calvinisdi Belanda. ${ }^{35}$ Di lembaran terahir buku Mazmur itu, dicamtumkan Katekismus Heidelberg.

Pada sidang Sinode di Dordrecht Belanda (1618-1619), Katekismus Heidelberg dibahas. Pada sidang sinode itu semua pejabat gereja, guru-guru besar, para bupati, para rektor universitas, kepala sekolah bertanda tangan sebagai bukti penerimaan Katekismus Heidelberg sebagai buku pengajaran agama Kristen bagi pemuda-pemudi di sekolah dan Katekisasi. Dan selanjutnya menjadi salah satu pengakuan iman Calvinis, selain pengakuan iman Gereja Belanda (1561) karangan Guido de Bres, dan pasal-pasal ajaran Dordrecht (1619). Keterlibatan semua pihak mendukung

\footnotetext{
${ }^{34}$ Ibid.

35 Nyanyian Mazmur Oude berijming umumnya di pakai oleh Jemaat CGK di Belanda yang menganggap bahwa mereka masih tidak kehilangan warisan-warisan ajaran Clavin (behaudende gemeente). Jemaat-jemaat yang dimaksud misalnya jemaat CGK di Bennekom, jemaat Baarn, jemaat Rijswijk yang termasuk dalam Klasis Amersfoort dan juga di jemaat Maranatha Urk. Tetapi kebanyakan jemaat-jemaat CGK sudah menggunakan Nyanyian Mazmur gubahan baru (Psalm van de niuwe berijming) karena banyak generasi muda yang merasa sulit menyanyikan Mazmur gubahan lama.
}

Katekismus Heidelberg juga membuktikan bahwa sejak awal katekismus ini mendapat dukungan positif walaupun ada pengaruh tekanan politik. Tentu saja konteks di mana katekismus ini disahkan sangat berperan penting. Katekismus Heidelberg tidak hanya di terjemahkan kedalam semua bahasa eropa termasuk bahasa Belanda, tetapi juga kedalam bahasa lain di dunia ini termasuk Indonesia.

Dari pembahasan sejarah singkat lahirnya Katekismus Heidelberg di atas, dapat disimpulkan bahwa: Pertama, Konteks lahirnya Katekismus Heidelberg sebagai materi pengajaran PAK dikatakan kontekstual karena lahir dari pergumulan Raja Friedrich III yang ingin pengikut Lutheran, pengikut Melanchthon dan Calvinis (Calvinis) hidup dalam keharmonisan. Jadi, Katekismus ini bersifat ekumenis. Kedua, Katekismus Heidelberg dapat disebut sebagai materi pengajaran PAK yang menyerap pengajaran-pengajaran yang sudah ada sebelumnya, seperti Katekismus-katekismus Luther dan lainnya yang disebutkan di atas. Jadi, Katekismus ini juga tidak mengabaikan peran para teolog yang sejak awal berusaha menjawab kebutuhan pengajaran PAK dari masa ke masa.

\section{Pokok-Pokok Pengajaran Katekismus Heidelberg sebagai Materi PAK di Gereja, Sekolah dan Rumah Tangga}

Pokok-pokok Pengajaran Katekismus
Heidelberg

\section{Persekutuan dengan Kristus.}

Tanpa persekutuan dengan Kristus tidak ada keselamatan. Pernyataan ini mengemuka dalam Katekismus 
Heidelberg, dan sangat relevan dengan salah satu motto Reformasi yaitu Sola gratia. Karena keselamatan hanya dapat diperoleh dalam Yesus Kristus sebagai satu-satunya anugerah Allah untuk menyelamatkan manusia melalui iman sejati. Pokok tersebut diungkapkan dalam jawaban pertanyaan no.20 bahwa "mereka yang oleh iman yang sejati dijadikan anggota tubuh-Nya dan menerima seluruh baptisan yang melalui tanda dan materai perjanjian Allah itu, orang percaya termasuk anak-anak mereka dimasukan ke dalam gereja Kristen dan Persekutuan dengan Kristus. Demikian pula dengan sakramen Perjamuan Kudus. Melalui sakramen ini kita menerima tanda dan materai, bahwa kita oleh Roh Kudus dijadikan anggota tubuh Kristus.

Sehubungan persekutuan dengan Kristus atau dengan kata lain menjadi anggota tubuh Kristus, Katekismus Heidelberg tidak melalaikan tanggung jawab manusia untuk menghasilkan buahbuah dari keselamatan dalam persekutuan mereka dengan Kristus. Dikatakan bahwa "tidak menghasilkan buah berupah perbuatan baik, yang timbul dari rasa syukur kepada Allah' (pertanyaan dan jawaban no.64 yang sejajar dengan pertanyaan dan jawaban no. 2 bagian c).

Kepercayaan terhadap keselamatan dalam persekutuan dengan Kristus menurut ajaran Katekismus Heidelberg tidak berhenti pada iman saja. Ia menuntut bukti yang nyata dalam kehidupan seharihari yaitu perbuatan-perbuatan yang baik atau dengan kata lain, etika. Dalam semua agama dikenal istilah mitos, ritus, dan etika. Di dalam lingkungan Kristiani secara sederhana kita dapat mengganti istilah "mitos" dengan "dogma", "ritus" dengan "liturgi" dan "etika" yang jelas bagi kita semua. ${ }^{36}$ Etika dalam "bahasa" Katekismus Heidelberg berupa perbuatan baik yang timbul dari rasa syukur kepada Allah. Jika hanya unsur pertama dan kedua yang terpenuhi, maka akan timbullah agama inklusif. Itulah yang menurut penulis diantisipasi oleh penyusun Katekismus Heidelberg. Dasar biblisnya misalnya Galatia 2:20, "Namun Aku hidup, tetapi bukan lagi aku sendiri yang hidup, melainkan Kristus yang hidup di dalam aku. Dan hidupku yang kuhidupi sekarang di dalam daging, adalah hidup oleh iman dalam Anak Allah yang telah mengasihi aku dan menyerahkan diri-Nya untuk aku", dan Yakobus 2:26, "sebab seperti tubuh tanpa roh adalah mati, demikian jugalah iman tanpa perbuatanperbuatan adalah mati”.

Sejak semula, gerakan Reformasi menekankan tentang persekutuan dengan Kristus. Dalam salah satu traktat (tesis) Martin Luther tentang kemerdekaan Kristen, dikatakan bahwa hanya di dalam persekutuan yang sejati dengan Kristus kita dapat berbicara tentang kebenaran Kristus yang dihadiahkan kepada kita. Dia telah mengambilalih dosa-dosa kita. Luther juga menggunakan ungkapan "kita serupa dengan Kristus dalam satu tubuh, satu kerangka, satu kuk dengan Dia".

Calvin dan juga Bucer menekankan persekutuan dengan Kristus. Penekanan itu dapat kita temukan dalam sumber teologi Calvin yang terkenal, Institutio. Dalam rumusan Institutio Calvin, dikatakan bahwa "Segala yang Kristus telah lakukan untuk keselamatan manusia tidak ada gunanya dan tidak ada artinya selama Kristus di luar kita dan kita terpisah dari Dia. Jadi, supaya Dia memberikan

\footnotetext{
36 Eka darmaputera, "Menuju Teologi Konstektual di Indonesia" dalam Eka Darmaputera (peny.), Konteks Berteologi di Indonesia (Jakarta: BPK Gunung Mulia cet. ke-4, 2004), 14 .
} 
kepada kita apa yang telah diterimanya dari Bapa maka ia harus menjadi kepunyaan kita dan diam dalam hati kita" (Bab I-III, III;1).

Persekutuan dengan Kristus terjadi melalui iman yang sejati seperti yang terdapat dalam pertanyaan dan jawaban no.20 Katekismus Heidelberg. Yang terpenting dari pertanyaan no. 20 adalah pengenalan tentang Roh Kudus yang membuat kita, oleh iman sejati beroleh bagian dalam Kristus dan segalah anugerah-Nya. Persekutuan dengan Kristus adalah pekerjaan Roh Kudus yang mengikat kita dengan Kristus melalui Firman Allah.

Dalam teologi Calvinis, hubungan antara Roh dan Firman diistilahkan dengan cum verbo (bersama dengan Firman). Menurut H. Berkhof, ${ }^{37}$ para teolog Calvinis tidak berani mengatakan bahwa "di mana Firman berada disitu juga ada Roh berada." Roh dapat bekerja di luar Firman dan Firman yang telah diberitakan bisa tanpa meninggalkan efek. Jika Firman itu mempunyai efek atau akibat, maka efek tersebut adalah penambahan dari pekerjaan Roh. Teologi ini berdasarkan pada beberapa ayat Alkitab misalnya dalam Kisah Para Rasul 16:4 tentang Lidia: "Tuhan membuka hatinya, sehingga ia memperhatikan apa yang dikatakan oleh Paulus". Menurut Berkhof, Firman adalah instrument Roh, tetapi Roh bukan tahanan Firman, juga Firman tidak bekerja secara otomatis. Firman membawa Roh ke dalam hati, dan Roh membawa Firman sampai kedalam (within) hati. ${ }^{38}$

Persekutuan dengan Kristus juga menyangkut pokok eklesiologi. Penggabungan di dalam Kristus adalah juga

\footnotetext{
${ }^{37}$ Hendrikus Berkhof, The Doctrine of the HolySpirit (Richmond, Virginia: John Knox Press, 1964), 37.

${ }^{38}$ Ibid. 38.
}

penghisapan di dalam tubuh-Nya yaitu jemaat Kristus. Hubungan mistik antara tubuh Kristus dan jemaat-Nya yang sehat akan menghasilkan kehidupan kegerejaan yang sehat, dan demikian sebaliknya. ${ }^{39}$

\section{Dibenarkan hanya oleh karena Iman - Fungsi Hukum Taurat}

Hubungan antara pertanyaan dan jawaban no.20-23 dengan pertanyaan dan jawaban no. 59-61 Katekismus Heidelberg sangat erat. Pertanyaan dan jawaban no. 20-23 Minggu ketujuh merupakan diskusi tentang iman yang sekaligus memperkenalkan Pengakuan Iman Rasuli yang dilanjutkan dengan diskusi tentang stuktur dan isinya. Pengakuan Iman tersebut, memuat ajaran tentang Trinitas: Bapa, Anak dan Roh Kudus. Jadi Pengakuan Iman dalam Katekismus ini mengajarkan tentang Allah Bapa (pertanyaan dan jawaban no.26-28), Allah Anak (pertanyaan dan jawaban no.29-52) dan Allah Roh Kudus (pertanyaan dan jawaban 53-64). Menurut Flooster pertanyaan no. 20-23 Katekismus Heidelberg secara singkat mempunyai dua pertanyaan: "Siapa yang di selamatkan?" dan "apa yang harus dipercayai oleh orang Kristen?"40

Selanjutnya pertanyaan dan jawaban no. 59-61 berbicara tentang manfaat kepercayaan kepada Pengakuan Iman yang telah diuraikan sebelumnya. Dikatakan bahwa di dalam Kristus dan di hadapan Allah aku benar dan dijadikan ahli waris hidup yang kekal (jawaban

\footnotetext{
${ }^{39}$ Den Hertog, De Kerk ende Middeler, \{Makalah ceramah kuliah dogmatika) (Apeldoorn: Theologische Universiteit Apeldoorn, September 2005), 11

40 Fred H. Flooster, Our Only Comfort A Comphensive Commentary on The Heidelberg Catechism, vol. 2 (Grand Rapids, Michigan: Faith Alive Christian Resources, 2001), 194.
} 
no.59). Ungkapan itu sekaligus merupakan jaminan penghiburan yang satu-satunya bagi orang percaya, yang diungkapkan pada pertanyaan dan jawaban no. 1 Katekismus itu.

Pernyataan "dibenarkan dihadapan Allah", sinonim dengan ungkapan "dibenarkan oleh iman sola fide, sola gratia, sola Christo,sola-Scriptura- "oleh Iman saja, oleh anugerah saja", Kristus saja", "hanya Alkitab"- itu semua adalah kata kunci gerakan Reformasi. ${ }^{41}$ Baik Martin Luther maupun Yohanes Calvin melandasi Gerakan Reformasi mereka pada motto-motto tersebut dan sekaligus merupakan "jantung" Reformasi. Bagian yang terpenting dalam pertanyaan dan jawaban no.20-23 dan no. 59-61 adalah sola fide. Tetapi tidak berarti bahwa yang lain kurang penting. Hanya dengan iman kepada karya Allah Bapa dalam Yesus Kristus untuk menyelamatkan dunia, maka kita akan dibenarkan di hadapan Allah dan sekaligus diselamatkan. Itulah iman yagn sejati. Menurut Karl Barth, iman itu bukan hanya suatu pengetahuan tetapi juga adalah kebenaran yang tulus atau iklas. ${ }^{42}$ Adalah jelas bahwa maksud Barth dengan ungkapan "kebenaran ini" adalah karya keselamatan Allah dalam Kristus. Lebih lanjut Karl Barth ${ }^{43}$ membagi tiga karakter iman itu, sebagai berikut:

Pertama, Karakter eskatologis dari penebusan melalui kebajikan Kristus. Sebab kita diselamatkan dalam pengharapan (Rom.8:24). Karena sekarang kita melihat dalam cermin suatu gambaran yang samar-samar (1 Kor.13:12). Dan kita sudah mengerti bahwa hanya anak-anak Allah saja sebagai buah pertama dari keselamatan yang telah dinyatakan.

\footnotetext{
${ }^{41}$ Ibid, 740

${ }^{42}$ Karl Barth, Inleiding,...53.

${ }^{43}$ Ibid.
}

Kedua, Kita tidak hanya berbicara tentang iman perseorangan sebagai kesimpulan keselamatan pribadi. Tetapi iman sebagai perlengkapan umum umat Allah. Jadi, iman dimengerti bukan hanya ungkapan-ungkapan individu tetapin juga ungkpan Gereja.

Ketiga, Kita telah memahami iman umat Allah sebagai perlengkapan Kristen untuk tugas-tugas dan pengutusan mereka dalam dunia, sebagai pemberita-pemberita Injil dan terang dunia. Menurut Yohanes Calvin, satu-satunya cara bagi manusia yang telah dikutuk oleh Hukum Taurat untuk memperoleh kembali keselamatan ialah melalui iman (Institutio Bab IX-XVIII, III Xii). Iman itulah yang membenarkan manusia di hadapan Allah. Pembenaran menurut Calvin adalah "diterimanya kita oleh Allah dalam anugerah-Nya dan pemilihan-Nya terhadap kitab sebagai orang yang benar. Pembenaran itu sendiri terletak di dalam pengampunan dosa dan dalam kita diperhitungkannya kebenaran Kristus kepada kita" (Institutio Bab XI-XVIII, III xi 2).

Terkait dengan keselamatan, teologi Calvinis mengajarkan bahwa keselamatan yang kekal tidak berdasarkan pada perbuatan-perbuatan baik atau jasa manusia. Ini bukan berarti kesalehan tidak penting sebab itu adalah buah-buah iman terhadap dasar keselamatan dari Allah yaitu pe-ngorbanan Kristus. Teologi Calvinis tidak memandang kemampuan manusia taat kepada Hukum Taurat (kalau ada yang mampu secara sempurna), sebagai dasar pembenaran di hadapan Allah.

Dalam Katekismus Heidelberg (pertanyaan no. 92-115) didiskusikan juga tentang pembagian Sepuluh Hukum Tuhan (pertanyaan no. 93), dan selanjutnya penjabaran dari masing-masing perintah Tuhan, yang secara singkat 
dibagi oleh Tuhan Yesus menjadi dua bagian; kasih kepada Allah dan kasih kepada sesama manusia (bdk. Matius 22:37-40).

Menurut Calvin, "Kristus adalah kegenapan Hukum Taurat, sehingga keselamatan diperoleh tiap-tiap orang (Roma 10:4). Bahwa "Kristus adalah Roh yang menghidupkan hukum tertulis yang mematikan selama hukum itu berdiri sendiri" (2 Kor. 3:6)" (dalam Institusi Bab VII, II, ii 2). Jadi, Hukum Taurat ditetapkan karena pelanggaranpelanggaran (Gal 3:19) supanya manusia diyakinkan bahwa mereka terkutuk dan dengan demikian menjadi rendah hati.

Dalam Institutio Calvin disebutkan bahwa Hukum Taurat sebagai "Hukum Kesusilaan", yang berfungsi sebagai "cermin", untuk dengan rasa takut akan hukuman, sekurang-kurangnya menahan orang-orang yang sama sekali tidak peduli akan keadilan dan kebenaran, untuk bangkit dan digerakkan oleh Roh sedemikian rupa, hingga menaati Allah, menjadi keinginan bagi mereka (Institutio Bab VII, II, VII 6-II, VII,12).

Demikian pula dalam ringkasan Dogmatika Calvinis karangan van Gerderen dan W. A Velema disebut trigma Hukum Taurat (triplex usus legiss) sebagai berikut: ${ }^{44}$ (a) Penggunaan biasa atau sipil (usus eivils, usus politicus); Hukum Taurat diberikan untuk mengekang atau mengendalikan dosa-dosa. (b) Penggunaan yang bersifat mendidik (usus normativus, usus didacticus). Hukum Taurat ada untuk meyakinkan adanya dosa-dosa. (c) Penggunaan normatif (usus normativus, usus didacticus); Hukum Taurat sebagai pedoman bagi orang-orang percaya.

${ }^{44}$ Van Gerderen en W.A. Velema, Op. Cit.,702.

\section{Perjanjian dalam Baptisan}

Baptisan Kudus mengandung keyakinan bahwa Kristus berkehendak membasuh dosa-dosa kita dengan darahNya, seperti yang dilambangkan oleh air baptisan yang membasuh kita. Dalam surat-surat Paulus, jelas bahwa Yesus sendiri sebagai kurban bakaran bagi Allah yang berkenan dan layak menggantikan kita.

Pada pernyataan dan jawaban no. 71 Katekismus Heidelberg terdapat tiga janji yang disebutkan. Pertama, janji dalam amanat untuk memberitakan Injil (Mat. 28:19). Melalui amanat itu, Allah berjanji untuk menyertai pemberitapemberita Injil, sehingga Injil itu tidak hanya diberitakan kepada orang-orang yang layak atau yang pantas saja. Walaupun memang diakui bahwa menurut ajaran Calvin ada orang yang dipilih dan ada yang tidak. Tetapi dalam kenyataannya, Allah tidak menyebut mereka dalam Injil itu. Jelas bahwa Allah melalui RohNya akan memberi keberhasilan bagi pemberita-pemberiata Injil. Kedua, terletak pada hubungan antara iman dan baptisan. Hanya dengan iman, kita mengerti tanda-tanda lahiriah itu, sebagai simbol persekutuan dengan Kristus. Ketiga, relasi antara baptisan dan kelahiran kembali setelah pembasuhan dosa. Hutang karena dosa-dosa kita tidak kurang dari pada noda dan kekuatannya. Yang pertama telah dibuang melalui pengampunan, dan yang kedua dilumpuhkan kekuatannya oleh pekerjaan Roh.

Pertanyaan dan jawaban no. 72 berbicara tentang "air baptisan": air baptisan bukan pembasuh dari dosa itu sendiri. Hanya darah dan Roh Kristus yang membersihkan dan memurnikan. Air itu adalah simbol lahiriah saja. Berbeda dengan ajaran Calvin, Luther mengajarkan bahwa baptisan adalah saluran 
berkat dan memandang air baptisan bukan sebagai tanda lahiriah tetapi sebagai sesuatu yang illahi. Menurut Luther air itu bersifat illahi, menyenangkan, subur, dan air yang kaya dengan berkat, air yang membuang kematian dan sengsara dan menolong kita di dunia dan di sorga. ${ }^{45}$

Visi Reformasi tentang baptisan kita temukan dalam pekerjaan Calvin dan di dalam Pengakuan-pengakuan iman yang tertulis. ${ }^{46}$ Kita percaya bahwa baptisan itu sendiri tidak membasuh dosa. Pada pertanyaan dan jawaban no. 69 dikatakan dengan jelas bahwa "Kristus telah menetapkan permandian lahiriah ini disertai janji." Dikatakan bahwa "sebagaimana tubuhku pasti dibasuh secara lahiriah oleh air, yang biasa dipakai untuk menghilangkan kotoran tubuh, sepasti itu pula aku telah dibasuh dengan darah dan Roh-Nya dari kecemaran jiwaku, yaitu semua dosaku." (jawaban no.69).

Pokok paptisan bayi atau anakanak, juga didiskusikan pada pertanyaan dan jawaban no. 74. Dapat dikatakan bahwa isi dari diskusi itu bertujuan untuk melawan aliran Anabaptis. ${ }^{47}$ Aliran ini ditolak oleh para Reformator termasuk

${ }^{45}$ Ibid., 715-716.

${ }^{46}$ J. van Genderon, De doop bij Calvijn (Kampen: J.H. Kok, 1983), 263.

${ }^{47}$ F.D. Wellem,Kamus Sejarah Gereja (Jakarta: BPK Gunung Mulia, cet. ke 4) 2006)16. (Kata Anabaptis berasal dari kata Yunani, ana dan baptizo yang berarti: membaptiskan kembali. Kata ini dipergunakan untuk menunjuk pada berbagai kelompok Kristen di Eropa Daratan pada abad ke-16 yang menolak anak-anaknya untuk dibaptiskan. Mereka menekankan baptisan orang percaya (dewasa). Nama ini merupakan nama sindiran yang diberikan kepada mereka oleh lawan-lawannya, karena mereka menolak baptisan anak sebagai baptisan yang benar. Mereka membaptiskan kembali anak yang telah menjadi dewasa. Itulah sebabnya merekadi sebut Anabaptis...).
Calvin. Anabaptis dihambat, baik oleh Gereja Katolik Roma maupun oleh Gereja Protestan. Mereka dihambat di mana-mana namun pada abad ke-19 mereka memperoleh kebebasan untuk hidup dan berkembang. ${ }^{48}$

Mengenai pokok itu, Katekismus Heidelberg berdasarkan pada Perjanjian Lama yakni ketika Allah mengadakan perjanjian dengan Abraham melalui tanda sunat (Kej 17:7), yang kemudian dalam Perjanjian Baru digantikan dengan baptisan, sebagai perintah atau amanat langsung dari Anak Allah yaitu Yesus. Calvin berkata, "anak-anak orang Yahudi disebut benih kudus" (bdk. Ezr 9:2) sebab mereka telah dijadikan ahli-ahli waris perjanjian dan dengan demikian dibedakan dari anak-anak orang fasik. Begitu juga karena alasan yang sama, anak-anak orang Kristen dianggap kudus, walaupun hanya seorang dari orang tua mereka yang percaya (1 Kor. 7:14) (Institusi Bab XVI, IV, xvi, 6). Demikian juga dalam Dogmatika Calvinis. Di sana ditunjukkan beberapa ayat Alkitab sebagai dasar mereka menyetujui baptisan anak. Antara lain adalah Kejadian 17:7, "Allah memberikan janjijanji-Nya bagi orang percaya dan anakanak mereka;" Kis 2:39 "untuk kamulah perjanjian ini dan anak-anakmu." Demikian juga dalam Kolose 2:11,12: "Dalam Dia kamu telah disunat, bukan dengan sunat yang dilakukan oleh manusia tetapi dengan sunat Kristus, yang terdiri dari penanggalan akan tubuh yang berdosa, karena dengan Dia kamu dikuburkan dalam baptisan dan dalam Dia kamu turut dibangkitkan juga oleh kepercayaan kepada kerja kuasa Allah yang telah membangkitkan Dia dari antara orang mati”.

\footnotetext{
${ }^{48}$ Ibid., 17.
} 
H. Berkhof mengatakan bahwa yang penting dalam baptisan adalah pengangkatan (opening) di dalam persekutuan, baik dengan Kristus maupun dengan jemaat. ${ }^{49}$ Ia pun mendukung baptisan anak dengan mengatakan bahwa Baptisan tidak tergantung dari iman yang dibaptis.

\section{Perjanjian dalam Perjamuan Kudus}

Pada pertanyaan dan jawaban no. 75-80 Katekismus Heidelberg, didiskusikan Perjamuan Malam Tuhan atau Perjamuan Kudus. Dalam pokok ini penekanan terletak pada persekutuan dengan Kristus. Ketika provinsi Palatinat dibawah pengaruh jalan pikiran Raja Friedrich III sebagai penganut Calvinis, persoalan Perjamuan Kudus juga menguak ke permukaan. Antara Gereja Katolik Roma dan Gereja Protestan terdapat perbedaan, bukan hanya pokok pembenaran Allah, tetapi juga pendapat mengenai misa Katolik Roma yang di dalamnya terdapat pokok "kurban."

Gereja Katolik Roma menekankan kurban Kristus yang dilaksanakan oleh imam pada altar. Gereja ini pun mengajarkan dogma transsubstansiasi (sejak 1215), yaitu roti dan anggur dalam ekaristi, oleh kekuatan ilahi sungguhsungguh berubah menjai tubuh Kristus dan anggur menjadi darah Kristus. Gereja Lutheran masih mirip dengan Gereja katolik Roma.

Luther sendiri tidak setuju dengan dogma transsubstansiasi dari Gereja katolik Roma, tetapi ia mengajarkan, bahwa terdapat suatu penyatuan yang sungguh-sungguh antara Kristus dengan elemen-elemen Perjamuan Kudus. Penyatuan itu seperti api dan dalam api

${ }^{49}$ H. Berkhof, Christelijk Geloof (Nijkerk: G.F. Callenbach B.V.,1973),368 yang membara. ${ }^{50}$ Menurut Luther, Kristus hadir secara badaniah dalam perjamuan Kudus. Kristus hadir tidak hanya di tempat-tempat tertentu di mana Perjamuan Kudus dirayakan, tetapi bersamaan dengan itu, Dia juga hadir di tempat lain. Dia hadir di mana-mana secara badaniah. ${ }^{51}$

Kemudian Gereja Calvinis mengacu pada ajaran Calvin dan juga Zwingli. Calvin mengajarkan kehadiran Kristus dalam Perjamuan Kudus tidak secara badaniah atau lahiriah, tetapi secara rohaniah. Hanya oleh iman kita ambil bagian dalam persekutuan dengan Kristus. Dan oleh karena misteri persekutuan yang tersembunyi antara Kristus dengan orang-orang saleh menurut hakekatnya sukar dipahami, maka diperlihatkan-Nya lah tokoh dan gambar dalam hal ini dengan tanda-tanda yang yang bisa dilihat, yang tepat sesuai dengan daya paham kita yang kerdil (Institusi Bab XVII). Menurut Calvin, pada waktu kita merayakan Perjamuan Kudus sebagai perintah Tuhan, kita menerima dalam hati iman bersama-sama dengan orang percaya, bahwa Kristu menderita dan mati untuk kita. ${ }^{52}$

Sejalan dengan ajaran Calvin, Katekismus Heidelberg dalam pertanyaan dan jawaban no. 75 mempersoalkan tentang bagaimana orang percaya mendapat bagian dalam kurban Kristus yang satu-satunya yang terjadi di atas kayu salib, dan dalam semua harta-Nya. Untuk menjawab pertanyaan tersebut maka kita perlu menunjuk kepada perintah atau amanat Kristus. Kristus berkata: "perbuatlah ini menjadi peringatan akan Aku." Amanat itu dimaterai dengan janji. Dalam janji itu penekanan jatuh pada ungkapan "untuk saya", "untuk saya

\footnotetext{
${ }^{50}$ Van Genderen, De doop...,730.

${ }^{51}$ Ibid. $730 \& 731$.

${ }^{52}$ Ibid., 731.
} 
tubuh Kristus dipecah-pecahkan dan darah-Nya ditumpahkan, sebagaimana aku melihat dengan mata kepala sendiri bahwa roti Tuhan dipecah-pecahkan untukku dan cawan diberikan kepadaku, sepasti itu pula tubuhnya dikurbankan bagiku dan darah-Nya ditumpahkan untukku di kayu salib" (jawaban no. 75 Katekismus Heidelberg).

Pembicaraan tentang "pemecahan" dan "penumpahan" yang kita saksikan dengan mata kepala kita adalah tandatanda lahiriah, yang menunjuk kepada janji Allah yang tetap. Allah mengenyangkan dan menyegarkan jiwaku sebagaimana ketika aku menerima tandatanda itu dan merasakan dengan mulutku. Secara rohaniah kita menerima seluruh penderitaan dan kematian Kristus dengan hati yang percaya. Dengan demikian, kita memperoleh pengampunan dosa dan hidup yang kekal serta persekutuan dengan Dia yang mana kita diperintah oleh satu Roh yang selama-lamanya, sama seperti anggota-anggota tubuh hidup dan diperintah oleh satu jiwa (jawaban ke-76).

Kristus melakukan itu semua melalui pekerjaan Roh-Nya. Oleh karena itu, kita boleh yakin seperti yang dikemukakan oleh formulasi Perjamuan Kudus: "Tidak pada tanda-tanda lahiriah, roti dan anggur kita terikat, tetapi hati kita terangkat ke sorga, di mana Kristus ada dan duduk di sebelah kanan Allah."Menurut ajaran Calvini, makan dan minum dalam Perjamuan Kudus berarti bahwa orang percaya memegang sengsara dan kematian Kristus untuk menerima pengampunan dosa. Jadi tidak ada pengampunan tanpa seluruh penderitaan dan kematian Kristus. Janji pengampunan dan hidup kekal diteguhkan pada meja perjanjian, seperti pada baptisan. Tetapi Perjamuan Kudus lebih lagi. Sakramen itu membawa kita pada suatu yang sangat istimewa di dalam persekutuan dengan Kristus sendiri. Tentang rahasia Perjamuan Kudus itu, Calvin mengatakan: "jika seseorang bertanya tentang cara Kristus hadir dalam Perjamuan Kudus, saya sendiri tidak akan malu-malu mengaku bahwa hal itu adalah suatu rahasia yang begitu tinggi, sehingga tidak dapat saya tangkap dengan akal atau saya ungkapkan dengan kata-kata" (Institutio, Bab XVIII, IV, Xvii, 32).

Selanjutnya, pertanyaan dan jawaban no. 80 masih menunjukkan gambaran penolakan terhadap ajaran Gereja Katolik Roma mengenai misa pada konteks abad ke-16. Penjelasan tentang Misa dalam pertanyaan dan jawaban ke-80 Katekismus Heidelberg dirumuskan sebagai reaksi kalangan Protestan di Jerman Selatan pada tahun 1563 atas keputusan Konsili Trente yang menyatakan bahwa semua warga Kristen Protestan "terkutuk" (anathema). Istilah "terkutuk" ini pada edisi pertama (Januari 1563) belum ada; istilah itu baru ditambahkan pada edisi-edisi berikutnya, setelah rumusan kutukan dari Konsili tersebut di atas diketahui oleh kaum Protestan itu. Agar kita mendapat pemahaman yang lebih akurat dan luas tentang arti Misa atau Ekaristi, berikut ini disajikan catatan penjelasan dari Konfersi Waligereja Indonesia (KWI): Misa atau Ekaristi adalah Sakramen Syukur. Inti Ekaristi adalah Doa Syukur Agung, yang diambil dari tradisi Yahudi dan dikaitkan dengan Penciptaan Baru dan Penyelamatan Yesus Kristus Melalui Wafat dan Kebaktian-Nya yang bersifat "final", artinya tidak dapat diulangi lagi, tetapi dalam 1 Korintus 11:23 dst. Dan Lukas 22:19 dst. Dinyatakan bahwa Kristus meminta para murid-Nya untuk mengenangkan ("anamnesis") penyerahan diri-Nya di salib dan Kebangkitan-Nya yang menyelamatkan lewat Ekaristi. 
Pengenangan akan wafat dan kebangkitan Kristus tersebut merupakan ungkapan iman bahwa sekarang ini Tuhan "benarbenar" dan "senyata-nyatannya" masih terus menyelamatkan kita. Dengan kata lain, Ekaristi mengungkapkan iman bahwa Kristus sekarang tetap hadir secara nyata di antara umat-Nya yang menyelamatkan kita. Kehadiran cinta kasih-Nya, bukan tergantung pada perbuatan baik atau upacara yang kita lakukan. Maka dengan demikian, Ekaristi bukan merupakan penyangkalan sengsara dan kurban Yesus Kristus yang satusatunya, dan lebih-lebih lagi bukan merupakan penyembahan berhala. Ekaristi adalah ungkapan iman dalam bentuk indrawi akan Allah yang hadir dan menyelamatkan bagi umat manusia yang berindra. ${ }^{53}$

Senada dengan penjelasan di atas, datang dari Calvinis Eucumenical Council (REC). Dalam dialog selama enam tahun antara perwakilan-perwakilan Gereja Kristen Calvinis di Amerika Utara dan pemimpin Gereja Katolik Roma, di Amerika dan Kanada, pihak Gereja Calvinis menyadari bahwa jawaban no. 80 Katekismus Heidelberg bersifat menghakimi. Dalam konteksnya "penghakiman" pertama Katekismus ini, antara lain: "Misa itu pada dasarnya tidak lain dan tidak bukan merupakan penyangkalan kurban dan penderitaan Yesus Kristus yang satu-satunya, dan penyembahan berhala yang terkutuk." Pernyataan ini terkesan tidak hati-hati. ${ }^{54}$ Pengajaran resmi Katolik menegaskan bahwa kurban Kristus sudah final, cukup, pengorbanan yang tidak disangsikan di atas salib dan bahwa Misa mem-

\footnotetext{
${ }^{53}$ Heidelberg Catcchism Q. \& A. and the Roman Catholic Eucharist Part 1 (2002); Revised 2004) dalam majalah REC FOCUS vol. 4, No 4, Desember 2004 p.67.

${ }^{54}$ Ibid., 68 .
}

berlakukan kembali atau menghadirkan kembali pengurbanan dan penderitaan itu dalam cara yang tidak berdarah (unbloody manner). ${ }^{55}$ Pengajaran Misa tersebut di atas merupakan pokok pembahasan Sidang REC di Belanda bulan juli 2005 yang lalu. ${ }^{56}$

Penjelasan di atas merupakan suatu kemajuan dalam usaha mengkontekstualisasikan Katekismus Heidelberg jawaban no. 80, untuk mengembangkan hubungan dan suasana oikumenis di antara Gereja Katolik dan Protestan dewasa ini. Tetapi warisan sejarah itu tidak boleh di hilangkan begitu saja, sebab bagaimana pun itu lahir dari konteks dan pergumulan tertentu, yang tetap mempunyai makna dan nilai sejarah.

\section{Disiplin Gereja}

Penjelasan dalam Minggu ke-21 (pertanyaan dan jawaban ke-54 Katekismus Heidelberg), menjelaskan bahwa Anak Allah atau Kristus oleh Roh dan Firman-Nya sejak awal dunia ini sampai akhir zaman, mengumpukan, melindungi, dan memelihara bagi diriNya dari segenap umat manusia, dalam kesatuan iman yangj benar, satu jemaat yang terpilih untuk beroleh hidup yang kekal. Allah Anak dalam mengumpulkan, melindungi dan memelihara jemaat-Nya, tidak hanya menggunakan Firman, tetapi juga sakramen-sakramen. Melalui sakramen Baptisan dan Perjamuan Kudus jemaat itu datang bersekutu.

Jemaat yang datang bersekutu akhirnya membentuk suatu struktur jemaat. Sejak awal Reformasi struktur jemaat-jemaat Calvinis mempunyai

\footnotetext{
${ }^{55}$ Ibid.

${ }^{56}$ Pdt. Dr. Kadarmanto Harjowasito: percakapan penulis, Jakarta, 29 Agustus 2007.
} 
perbedaan. Struktur jemaat di Zurich, misalnya pemerintah dipandang sebagai organ yang juga mengurusi perkaraperkara gerejawi. Negara Kristen akhirnya sama dengan jemaat Kristen. Campur tangan pemerintah atau Negara sangat besar dalam mencampuri urusanurusan gereja terutama dalam hal pembiayaan oprasional gereja, tetapi juga penerapan disiplin gereja. Tetapi di Jenewa oleh pengaruh Calvin, disiplin gereja dipisahkan dengan tegas dari kekuasaan pemerintah. Majelis Gereja sebagai organ yang oleh jemaat diangkat untuk menangani perkara-perkara dalam jemaat (jawaban no. 85). Model struktur jemaat di Jenewa tidak mudah diterima oleh kebanyakan orang termasuk pemerintah dalam jangka waktu yang lama. Barulah pada pertengahan tahun 50 abad XVI pemerintah menerima model tersebut.

Dapatlah dipastikan bahwa pada waktu penyusunan Katekismus Heidelberg telah terjadi debat pendapat dalam menentukan pilihan; memilih struktur gereja di Zurich atau yang di Jenewa, ${ }^{57}$ karena tim penyusun Katekismus tersebut terdiri dari teologteolog Calvinis yang berbeda. Tetapi dalam Katekimus Heidelberg telah di perlihatkan bahwa sebenarnya yang dipilih adalah model struktur Gereja Calvinis di Jenewa, Perancis, dan Skotlandia tanpa menyebutkan penolakan tehadap model struktur gereja Calvinis di Zurich. Pendapat yang lain adalah bahwa penyusunan utama Katekismus Hidelberg, Olevianus, dan Ursinus sebelumnya telah banyak dipengaruhi ole ide-ide Calvin termasuk model struktur Gereja. $^{58}$

57 W. van 't Spijker "The Theologie van de Heidelberg Catechismus" dalam W. van 't Spijker (ed.), Het troostboek...,144.

${ }^{58}$ Ibid.
Disiplin gereja oleh gereja Calvinis dilihat sebagai sarana pelayanan dalam pembangunan jemaat kepada kesuciaan umat di hadapan Allah. Dalam Katekismus Heidelberg dinyatakan bahwa orang yang mengajarkan ajaran sesat (pada waktu itu termasuk ajaran Anabaptis dan Gereja Katolik Roma), atau cara hidup yang keji, namanya harus di beritahukan kepada jemaat, atau kepada Majelis Gereja. Kalau mereka tidak menghiraukan Jemaat, Majelis Gereja akan mengucilkan mereka dari jemaat Kristen dengan cara melarang mereka menerima pelayanan sakramen Kudus, dan oleh Allah sendiri mereka dikucilkan pula dari Kerajaan Kristus.Dalam hal ini, teologi Calvinis menekankan kuasa atau wewenang Gereja menjalankan atau menerapkan disiplin Gereja yang menyangkut disiplin di bidang kesusilaan. Wewenang itu tentunya didasarkan pada ajaran Calvin. Calvin berkata: "pokoknya kekuasaan peradilan itu tidak lain dari suatu tertib yang diterapkan untuk memelihara pemerintahan rohani dalam persekutuan umat Tuhan. Untuk tujuan itu, ditetapkan majelis-majelis yang harus mengawasi dan memeriksa kesusilaan, memeriksa kesalahan-kesalahan, dan menyelenggarakan jabatan gerejawi' (Istitutio Bab XI, XII, IV, xi, 1). Kunci-kunci yang disebutkan Calvin maksudnya adalah kunci-kunci Kerajaan Allah seperti yang di jelaskan dalam Matius 18:18.

Karena pentingnya disiplin gereja dalam teologi Calvinis sehingga dalam Pengakuan Iman Gereja Belanda misalnya, pada pasal 29 dikatakan bahwa salah satu ciri khas gereja yang sejati adalah penyelenggaraan disiplin gereja untuk menghukum dosa. ${ }^{59}$ Dalam konteks

\footnotetext{
${ }^{59}$ Th. Van den End (menyeleksi), Enam Belas Dokumen..., 44.
} 
penyusunan pengakuan Iman Belanda, Guido de Bres sebagai penyusunnya memandang gereja-gereja yang tidak menerapkan lagi disiplin gereja sebagai gereja palsu. ${ }^{60}$ Salah seorang teolog Calvinis yang sangat setia kepada Pengakuan Iman Belanda adalah K. Schilder yang telah mengklaim gerejagereja Calvinis sebagai satu-satunya gereja yang benar dan yang lain adalah sekte-sekte. Ia berkata: "di Belanda tidak ada gereja yang lain di luar Gereja Calvinis yang tetap memberitakan Firman Allah yang murni, melayankan sakramensakramen yang benar, dan menerapkan disiplin Gereja". ${ }^{6}$

\section{Penebusan dan Pembaruan}

Penghiburan yang di sebutkan pada Minggu I Katekismus Heidelberg adalah pekerjaan Roh Kudus. Roh Kudus Kristus menguatkan kita untuk percaya kepada pengharapan hidup yang kekal. Roh Kudus yang sama membuat kita makin kuat untuk hidup di dalam pemeliharaan-Nya. Semua itu di latarbelakangi oleh penebus dosa-dosa kita oleh Kristus. Pada pertanyaan dan jawaban no. 7 dan no. 23 Katekismus Heidelberg dikatakan bahwa kepastian pengampunan bersandar pada karakter jasa-jasa Kristus. Kepastian pengampunan itu sangat erat hubungannya dengan kehidupan kekal. Dan kehidupan kekal itu juga berhubungan dengan pembaruan kehidupan yang bersyukur atas penebusan Allah itu. Di mana kita hidup oleh Kristus dan kehidupan kita terikat dalam Allah.

Pokok-pokok muncul kembali dalam pembicaraan ucapan syukur manusia atas kebaikan Allah. Pertanyaan

\footnotetext{
${ }^{60}$ J.W.Maris: Wawancara penulis, Apeldoorn, Belanda 10 November 2006.

${ }^{61} \mathrm{~J}$. Van Genderen, De Doop..., 62.
}

dan jawaban no. 16 Katekismus Hidelberg adalah sebuah ringkasan yang jelas tentang alasan mengapa manusia melakukan perbuatan baik sebagai wujud ucapan syukur kepada Allah. Alasannya adalah Kristus setelah menebus kita dengan darah-Nya. Jadi, Kristus menebus kita dan setelah itu membarui kita. Pertama-tama adalah Golgota, kemudian ke-bangkitan dan Keturunan Roh Kudus. ${ }^{62}$

Maksud Penebusan dan Pembaruan yang di lakukan Kristus dan Roh-Nya pertama-tama pujian dan kemuliaan yang harus di persembahkan kepada Allah. Kedua, kepastian bahwa iman kita adalah iman yang sejati, atau dengan kata lain: Kristus yang kita percayai juga adalah Tuhan yang betul-betul di salibkan dan bangkit serta menjadi juruselamat manusia. Kristus mengerjakan iman dan pertobatan didalam kita. Iman dan pertobatan terjalin bersama-sama; dan maksud dari semua itu adalah supaya semua manusia dimenangkan untuk Kristus.

Kehidupan dalam Kristus ditandai sekarang, melalui kematian manusia lama dan kebangkitan manusia baru (pertanyaan dan jawaban no. 88). Isi dari pertanyaan dan jawaban no. 88 Katekismus Heidelberg itu adalah kesadaran bahwa melalui persekutuan dengan Kristus kita ambil bagian dalam pederitaan-Nya. Kita mati dalam diri kita sendiri dan dalam dosa kita tetapi sekaligus kita hidup dari Dia dan dibaharui oleh Dia oleh Roh-Nya.

\section{Bagian terpenting dari Ucapan Syukur}

Diskusi tentang Doa Bapa Kami dalam pertanyaan dan jawaban no. 116-

\footnotetext{
${ }^{62}$ W.Van 't Spijker, "Theologie van de Heidelberg Catechismus" dalam van "t Spijker (ed), Het troostboek...,145-146.
} 
129 Katekismus Heidelberg dapat dipandang sebagai ringkasan dari apa yang di ajarkan oleh Katekismus ini sebelumnya. Ketiga pokok penting yang dikemukakan pada bagian awal Katekismus Heiddelberg dengan jelas kembali muncul dalam bagian ter-akhir. Dalam bagian ini dikemukakan sikap manusia yang telah belajar mengenal Penghiburan Injil, yang pada akhirnya tiba pada kesadaran bahwa Penghiburan itu tidak dapat diterima tanpa berkeluhkesah dengan tiada henti-hentinya memohon rahmat serta Roh itu dari-Nya dan mengucap syukur atasnya. Itulah doa menurut Katekismus Heidelberg. Doa itu merupakan bukti bahwa manusia penuh dengan dosa dan kelemahan.

Tetapi selain dosa dan kelemahan sebagai dasar dari sengsara manusia, juga sangat penting unsur penebusan oleh Allah dalam Kristus, sehingga menjadi alasan Allah mendengar doa yang dipanjatkan kepada-Nya melalui Yesus Kristus. Pertanyaan dan jawaban no. 117 Katekismus Heidelberg memuat beberapa unsur yang harus ada di dalam doa, yaitu: Seruan kepada Allah yang Esa dan Sejati; Keinsafan akan kelemahan dan kekurangan, dan Kepastian yang kuat dan penerimaan pengabulan doa serta permohonan kita.

Menurut Katekismus Heidelberg pada pertannya dan jawaban no. 118, Allah memerintahkan agar kita memohon kepada-Nya segala kebutuhan rohani dan jasmani yang disimpulakan Tuhan Yesus dalam doa yang di ajarkan-Nya sendiri kepada kita (Mat. 6:9-13; Luk. 11:2-4). Doa yang Tuhan Yesus ajarkan yang disebut Doa Bapa Kami, mempunyai makna yang sangat penting karena Yesus menyebut Allah sebagai Bapa. Menjadi suatu penghiburan kita karena Dia berkenan menjadikan kita anak-anakNya. Doa Bapa Kami berbicara tentang keyakinan pada pemeliharaan Allah seperti seorang ayah yang memelihara tubuh dan jiwa anak-anaknya. Di sini terdengar lagi elemen-elemen Minggu I (Pertanyaan no. 1) Katekismus Heidelberg: "dengan tubuh dan jiwaku bukan milikku tetapi milik dari Allah Tritunggal."

Pemakluman Yesus mengenai Kerajaan Allah, mewahyukan secara baru mengenai siapakah Allah itu. Yesus menyebut Allah, Abba, Bapa tercinta. Kebangkitan Yesus meneguhkan "tuntutan"-Nya sebagai Anak Allah. Para murid Yesus diajarkan berdoa "Bapa Kami". Partisipasi dalam kehidupan "Anak" itu sesudah kebangkitan-Nya dipahami sebagai buah daya Roh Kudus, Roh yang datang dari Allah melalaui anak-Nya yaitu Yesus. Daya Roh Kudus itu tidak terbatas pada sekelompok orang saja, tetapi untuk semua orang yang percaya. Selain itu, menurut penulis, pemahaman Allah sebagai Bapa semestinya mendorong murid-murid Kristus untuk membangun suatu persaudaraan dengan semua orang.

\section{Katekismus Heidelberg Sebagai Materi PAK bagi Gereja, Sekolah, dan Rumah Tangga}

Katekismus Heidelberg bukanlah satu-satunya Katekismus yang bercorak teologi Calvin. Sebelumnya, sudah ada Katekismus Jenewa atau Katekismus Calvin (1536/1545) yang diterima umum di Gereja-gereja Calvinis berbahasa Perancis.Terdapat Katekismus Anglikan (1549) ditujukan kepada Gereja Nasional Kerajaan Inggris dan juga Katekismus Westminster yang Besar dan yang Kecil (1647). Katekismus yang terakhir ini sampai sekarang beribawah besar dalam gereja-gereja Calvinis berbahasa Inggris. 
Katekismus Heidelberg sendiri, menjadi pedoman pengajaran agama dan kitab pengakuan iman dalam Gereja-geraja Calvinis berbahasa Jerman dan Belanda.

H. Flooster mengatakan bahwa setelah Katekismus Heidelberg diterbitkan, maka pendukung-pendukung lahirnya Katekismus itu mengirim salinansalinannya ke seluruh daerah Eropa. ${ }^{63}$ Informasi ini membuktikan bahwa Raja Friedrich III berkeinginan menyebarkan Katekismus Heidelberg bukan hanya di daerah kekuasaanya, tetapi juga ke seluruh Eropa.Pada tahun 1563 telah terbit edisi I-IV Katekismus Heidelberg. Edisi III Katekismus Heidelberg telah ditejemahkan ke dalam bahasa Latin oleh Joshua Lago (Lagio) seorang pendeta di Heidelberg dan Lambert Pithgopoeus (Pithozaeus) seorang guru di Heidelberg yang berasal dari kota Deventer, Belanda, Penerjemah ke dalam bahasa Latin itu dilaksanakan atas perintah Raja Friedrich III sendiri pada tanggal 19 Januari $1563 .^{64}$

Dengan terbitnya Katekismus Heidelberg dalam bahasa Latin, maka Katekismus itu menjadi terkenal di sekolah-sekolah dan lingkungan Universitas, khususnya di Jerman sebagai materi PAK. Kala itu, bahasa Latin dianggap sebagai bahasa akademik. Penerbitan ini disampaikan oleh Olevianus kepada Calvin melalui suratnya pada bulan April $1563 .^{65}$ Tindakan Olevianus tersebut membuktikan bahwa pengaruh Calvin dalam penyusunan Katekismus Heidelberg serta proses penggunaannya sangat penting. Tentang penggunaan Katekismus

\footnotetext{
${ }^{63} \mathrm{H}$. Flooster, The Heidelberg Catechism, The History and Origin and History (Grand Rapids, Michigan: Calvin Theological Seminary, 1985), 180.

${ }^{64}$ Ibid., 187.

${ }^{65}$ Ibid.
}

Heidelberg di Jerman, Flooster mengatakan bahwa Ursinus, sebagai salah seorang teolog dan penyusun Katekismus Heidelberg menggunakan Katekismus itu sebagai pedoman kuliah-kuliah dogmatika yang diajarkan di Heidelberg, dan dari kuliah-kuliahnya itu terbitlah Komentar Katekismus Heidelberg. ${ }^{66}$ Jadi, sejak semula fungsi Katekismus Heidelberg adalah pedoman pengajaran dogmatika di lingkungan fakultasfakultas teologi di Heidelberg dan sekitarnya. Menurut J.W. Maris, tradisi penggunaan Katekismus Heidelberg sebagai pedoman pengajaran dogmatika di Universitas-universitas Teologi di Jerman merupakan bukti sejarah kedudukan utama buku penghiburan gereja itu dalam lingkungan Gereja Calvinis di Jerman. ${ }^{67}$ Tetapi penggunaanya pun tidak terbatas di lingkungan akademik, karena para teolog yang telah belajar di universitas-universitas teolog turut menyebarkan Katekismus tersebut kepada masyarakat. $^{68}$

Fungsi Katekismus Heidelberg secara formal juga terlihat dalam edisi IV Katekismus tersebut yang kemudian menjadi bagian integral dari Gereja Palatinat pada tanggal 15 November 1563. Katekismus Heidelberg ditempatkan di antara bentuk-bentuk liturgi sakramen Baptisan dan Perjamuan Kudus. Hal itu menandakan bahwa, Katekismus Heidelberg mempunyai fungsi pengajaran. Fungsi pengajaran Katekismus Heidelberg sebenarnya telah di tegaskan oleh Raja Friedrich III dalam kata pengantar Katekismus Heidelberg edisi IV. Ia berkata: Di dalam Agama

\footnotetext{
${ }^{66}$ Ibid.

${ }^{67}$ J.W. Maris, "De Geschidenis van Cathecismus Heidelberg", kuliah Symboliek, Teologische Universiteit Apeldoorn, Nederland 13 Maret 2006.

${ }^{68}$ Ibid.
} 
(kepercayaan) Kristen kita, istilah "Katekismus" berarti rangkuman pengajaran lisan yang sederhana mengenai pokok-pokok utama doktrin agama Kristen, yang mana anak-anak muda dan mereka yang tidak terpelajar diwajibkan mengungkapkan/mengulangi apa mereka telah pelajari. Sudah kebiasaan bagi orang tua yang bijaksana sejak permulaan Gereja Kristen untuk mengajar anak-anak mereka takut kepada Tuhan di rumah, di sekolah dan di Gereja, tanpa ragu-ragu dengan alasan-alasan sebagai berikut: Pertama-tama dapat disimpulkan bahwa kejahatan natural manusia menambah pengaruh dan angin jahat yang merusak Gereja dan Negara. Yang kedua mereka didorong oleh perintah Allah yang jelas: Keluaran 12,13; Ulangan 4,6 dan 11 dan juga pasal 6:6 dan 7. Sebagai anak-anak Israel yang sudah disunat, mereka diajar mengenai pentingnya ucapan keagamaan dan berada dalam perjanjian Allah, sehingga anak-anak kita yang sudah dibaptis diajar Iman Kristen dan pertobatan, bahwa mereka boleh mengakui Iman mereka di hadapan jemaat Kristen yang hadir sebelum mereka diizinkan ambil bagian dalam meja Tuhan. ${ }^{69}$

Selama kurang lebih tiga ratus tahun pengajaran Katekismus Heidelberg dirasakan oleh gereja-gereja Calvinis sangat bermanfaat untuk pertumbuhan iman jemaat. Pada ulang tahun ketigaratus Katekismus Heidelberg tahun 1863, Gereja Calvinis Jerman telah menerbitkan edisi Katekismus Heidelberg dalam bahasa Jerman, Latin, dan Inggris. $^{70}$

Setelah Katekismus Heidelberg diterjemahkan kedalam bahasa Belanda,

\footnotetext{
${ }^{69}$ T.M Hofman "Kerkelijke Erkenning in de Catechismus" dalam W. Van't Spijker (ed.) Het troostboek...,191.

${ }^{70}$ Ibid., 187.
}

maka beberapa Sidang Sinode yang diselenggarakan membahas penggunaanya dalam jemaat-jemaat Calvinis di Belanda. Siding Sinode Gereja Calvinis Belanda yang membahas Katekismus Heidelberg adalah Sidang Sinode Wezel (1568), Sidang Sinode Emden (1571), Sidang Sinode di Dordrecht (1574 dan 1578), Sidang Sinode Middelburg (1581), dan Sidang Sinode Dordrecht (1618/1619). Penulis akan membahas beberapa penekanan dari beberapa Sidang Sinode tersebut di atas:

\section{Sidang Sinode di Wezel $(1568)^{71}$}

Pembahasan

Katekismus

Heidelberg pada Sinode Wesel Khususnya dalam artikel 2 pada dasarnya menekankan katekisasi bagi anak-anak muda. Sidang Sinode di Wesel itu masih berkonsentrasi pada pentingnya didikan bagi anak-anak baik dirumah maupun di sekolah. Tentang penggunaan dan fungsi Katekismus Heidelberg direkomendasikan pada Sidang Sinode berikutnya.

\section{Sinode Sinode di Emden $(1571)^{72}$}

Artikel V Keputusan Sidang Sinode di Emden memerintahkan penggunaan Katekismus Heidelberg terutama bagi jemaat-jemaat berbahasa Belanda. Keputusan ini merupakan "pintu" pertama diterimanya Katekismus Heidelberg dalam gereja-gereja Calvinis di Belanda.

\section{Sidang Sinode di Dodrecht $(1574)^{73}$}

Pada tanggal 16 Juni 1574, Sidang Sinode Dodrecht memutuskan penggunaan Katekismus Heidelbarg di seluruh

\footnotetext{
${ }^{71}$ Ibid., 186.

${ }^{72}$ Ibid., 187.

${ }^{73}$ Ibid., 187-188
} 
Gereja Calvinis di semua provinsi. Semua anggota jemaat, dan khususnya para pendeta harus mempelajari dan menyelidiki Katekismus Heidelberg. Sidang Sinode juga memutuskan bahwa setelah perayaan sakramen Perjamuan Kudus dalam Ibadah sore, khotbah yang berpedoman pada Katekismus itu harus dilayankan oleh para pelayan Firman. Sidang Sinode Dodrecht juga memutuskan pemberian tugas kepada pelayanpelayan Firman (para pendeta) untuk mengurus para guru di sekolah-sekolah supaya mendatangi Pengakuan Iman Belanda, tunduk kepada Tata Gereja, dan mengajarkan Katekismus Heidelberg kepada anak-anak muda (murid-murid mereka).

Jadi, Sidang Sinode Dordrecht 1574 telah melihat fungsi Katekismus Heidelberg sebagai pengajaran iman Kristen bagi anak-anak muda dan kedudukannya sama dengan ke-37 pasal Pengakuan Iman Belanda karangan Guido de Bres.

\section{Sidang Sinode Dordrecht $(1578)^{74}$}

Sidang Sinode di Dordrecht tahun1578 membahas pengajaran iman Kristen, sakramen-sakramen dan hari-hari raya. Pengakuan Iman Belanda (NGB), dinyatakan sebagai Pengakuan Iman yang memiliki fungsi penting. Para pemberita Firman, para profesor dan penatuapenatua diwajibkan membubuhkan tanda tangan sebagai bukti penerimaan Pengakuan iman itu.

Dalam pasal IV artikel 2 Keputusan Sidang Sinode Dodrecht ditekankan mengenai penggunaan Katekismus Heidelberg dan Mazmur yang telah diterjemhkan oleh Petrus Datheen di jemaat-jemaat berbahasa Jerman (Duite

${ }^{74}$ Ibid., 188. gemeente). Sedangkan jemaat-jemaat di Belgia menggunakan Katekismus Heidelberg bersama dengan Mazmur yang berbahasa Perancis. Sidang Sinode juga mengizinkan jemaat-jemaat Calvinis berbahasa Jerman untuk menyelidiki pengakuan iman yang terkandung di dalam Katekismus. Mereka pun diizinkan mencetak Katekismus tersebut bersama dengan kitab Mazmur terjemahan Datheen sebagai pedoman pengajaran bagi mereka.

\section{Sidang Sinode Middelburg $(1581)^{75}$}

Keputusan Sidang Sinode Dordrecht tahun 1578 menekankan penggunaan Katekismus Heidelberg pada ibadah hari Minggu sore. Hal itu juga menjadi topic perhatian dan pembahasan pada Sidang Sinode Middelburg. Hanya, penekanan pada penggunaan Katekismus Heidelberg pada perayaan sakramen Perjamuan Kudus (sesui keputusan Sidang Sinode Dordrecht 1574 dan 1578), tidak lagi dipaksakan. Jemaatjemaat diberi kebebasan. Keputusan itu diambil setelah Sidang Sinode mendengarkan dan membahas permintaan utusan dari klasis Brabant untuk tidak lagi berpatokan pada keputusan yang lama. Jadi, Sidang Sinode kali ini telah memberikan kebebasan kepada jemaatjemaat untuk menentukan sendiri cara yang dianggap tepat dalam menggunakan Katekismus Heidelberg.

Menurut seorang pendeta Gereja Calvinis di Belanda ${ }^{76}$ kenyataan bahwa Katekismus Heidelberg tidak digunakan lagi oleh kebanyakan jemaat-jemaat CGK di Belanda, di latarbelakangi oleh keputusan Sidang Sinode di Middelburg

\footnotetext{
${ }^{75}$ Ibid.

${ }^{76}$ J. Nutma, Wawancara penulis, Apeldoorn, Belanda 13 April 2007.
} 
1581 tentang kebebasan penggunaan Katekismus Heidelberg.

\section{Sidang Sinode Den Haag $(1586)^{77}$}

Pada Sidang Sinode di Den Haag, telah diputuskan pemberian peranan kepada Majelis Gereja untuk mengawasi para guru di sekolah-sekolah dalam menggunakan Katekismus Heidelberg sebagai pengajaran iman (artikel 19). Tujuannya agar para guru tidak hanya mengajarkan anak murid-murid mereka membaca dan menulis, tetapi juga belajar tentang kebaikan Allah yang diajarkan oleh Katekismus Heidelberg. Jadi, kerjasama antara Majelis Gereja dan para guru ingin digalakkan pada waktu itu. Menurut salah seorang penatua di jemaat Andreas CGK di Belanda, banyak anggota Majelis Gereja yang sekaligus sebagai guru di sekolah-sekolah. Dengan demikian mereka sebenarnya mengawasi diri mereka sendiri. ${ }^{78}$

Sidang Sinode di Den Haag juga kembali menetapakan penggunaan Katekismus Heidelberg pada ibadah hari minggu sore dimana para pendeta harus menjelaskan secara singkat dasar pengajaran Agama Kristen yang terkandung dalam Katekismus tersebut. Kembali ditegaskan bahwa pembagian Katekismus Heidelberg kedalam 52 minggu, dimaksudkan agar penggunaanya lebih praktis dalam satu tahun.

\footnotetext{
${ }^{77}$ T.M. Hofman,T.M Hofman "Kerkelijke Erkenning in de Catechismus" dalam W. Van't Spijker (ed.) Het troostboek...,184.

${ }^{78}$ Karel Buitenhuis wawancara penulis, Apeldoorn, Belanda 16 Juli 2006.
}

Sidang Sinode Dordecht $(1618 / 1619)^{79}$

Pada Sidang Sinode Dordrecht 16/1619 telah banyak desakan dari para teolog dan politisi untuk merevisi pengakuan iman tertulis termasuk Katekismus Heidelberg. Seranganserangan argumentasi dari pihak Remonstran yang sering samar-samar dan kurang jelas dihadapi oleh para peserta Sidang Sinode. Serangan-serangan itu dimunculkan oleh mereka melalui anggota-anggota mereka diantaranya Hugo Grotius dan Van Oldenbarnavelt. Mereka menyampaikan sebuah tulisan pada tanggal 21 Oktober 1618 yang berisikan kritikan terhadap Pengakuan Iman Belanda dan Katekismus Heidelberg. Mereka mengajukan pertanyaan-pertanyaan seperti "bagaimana manusia seharusnya melihat kekuatan dan wibawa mereka dalam hubungannya dengan Kitab Suci?' Selain itu, mereka juga menyerahkan surat keberatan terhadap Katekismus Heidelberg kepada peserta Sidang Sinode itu.

Reaksi peserta Sidang Sinode waktu itu terhadap kritikan mereka mengenai dokumen-dokumen Pengakuan Iman, sama dengan reaksi Sidang Sinode terhadap pernyataan kaum Remonstran yang menolak ajaran predestinasi Calvin. Sidang Sinode tidak menanggapi pertanyaan-pertanyaan kaum Remonstran itu, karena dianggapan mengada-ada.

Setelah mempertimbangkan berbagai aspek, akhirnya para Remonstran diusir dari Sidang Sinode pada tanggal 14 Januari 1616. Pembahasan Katekismus Heidelberg dalam Sidang Sinode di Middelburg selanjutnya adalah penyelidikan terhadap persesuaian atau

\footnotetext{
${ }^{79}$ T.H. Hofman, T.M Hofman "Kerkelijke Erkenning in de Catechismus" dalam W. Van't Spijker (ed.) Het troostboek...,189-192.
} 
kecocokan antara katekismus Heidelberg dengan Firman Allah. Semua pertanyaan dan jawaban Katekismus Heidelberg dibacakan dalam persidangan itu. Dan pada persidangansore harinya, melalui para teolog dari dalam dan luar negeri dinyatakan bahwa Katekismus Heidelberg secara keseluruhan didasarkan pada Firman Tuhan. Tidak ada yang perlu diubah.

Pengajaran terhadap murid katekisasi juga sangat mendapat perhatian dari Sidang Sinode di Dordrecht tersebut. Pembahasan itu dilaksanakan pada tanggal 28 November 1618. Dalam pembahasan tersebut para teolog dari dalam dan luar negeri ikut mengambil bagian. Pada saat itu muncul keinsafan mendalam akan fungsi Katekismus Heidelberg di lingkungan rumah tangga, di sekolah-sekolah dan dalam ibadahibadah di gereja. Para teolog juga memberi petunjuk-petunjuk, antara lain petunjuk pengajaran (didactishe aanwijzingen) kepada para guru sesuai pembagian umur dari anak-anak didik mereka, pemilihan jawaban-jawaban yang panjang, keharusan repetisi pelajaran, pemberian pengharapan kepada murid sebagai pendorong belajar, pemeliharaan keteraturan dalam mengikuti ibadah, dan lain-lain sebagainya.

Peranan penting orang tua dalam pengajaran Katekismus Heidelberg kepada anak-anak mereka di rumah, juga ditekankan dalam Sidang Sinode tersebut diatas. Tetapi juga diharapkan peranan yang maksimal dari para magistrate serta suri teladan mereka yang baik, untuk mendukung pelaksanaan pengajaran Katekismus Heidelberg di sekolahsekolah.

Pada tanggal 30 November 1618, Sidang Sinode itu juga memutuskan menyusun katekismus lebih kecil untuk anak-anak dan remaja. Ds. Gomarus, ds.
Polyandres, ds. Thysius, ds. Faukelius, ds. Lydius dan ds. Iderman diberi tanggung jawab untuk menyusun kedua Katekismus yang dibutuhakan itu. Katekismus bagi anak-anak dan remaja tersebut harus merupakan ringkasan Katekismus Heidelberg yang disusun dengan tujuan menolong anak-anak mengerti pokok-pokok ajaran Katekismus Heidelberg sesuai konteks anak-anak dan remaja. Kedua katekismus itu tidak boleh mengurangimakna teologi Katekismus Heidelberg itu sendiri. ${ }^{80}$

Kreativitas peserta Sidang Sinode di Dordrecht tahun 1618/1619 kemudian telah meringkaskan pengajaran Katekismus Heidelberg untuk anak-anak sesuai dengan kelompok umur. Itu merupakan bukti keseriusan Gereja Calvinis di Belanda untuk menanamkan ajaran Katekismus Heidelberg kepada anak-anak segala umur pada khususnya, dan kepada semua anggota jemaat pada umumnya pada waktu itu.

Pembahasan

Katekismus

Heidelberg secara umum telah menjadi tema sentral pada sidang-sidang Sinode Gereja Calvinis di Belanda dalam kurung waktu dari tahun 1571 sampai dengan tahun 1619 seperti yang telah dipaparkan di atas. Sidang Sinode di Den Haag tahun 1586 telah membahas pemberitaan Firman Allah dengan menggunakan Katekismus Heidelberg pada ibadah hari Minggu sore atau pada ibadah ke-2 hari minggu. Keputusan itu masih dipegang oleh sebagian kecil jemaat-jemaat Gereja Calvinis di Belanda, sedangkan sebagian besar tidak lagi mengikuti tradisi itu dengan alasan yang beragam. ${ }^{81}$ Sidang Sinode di Dordrecht 1618/1619 lebih mendalam lagi membahas persesuaian

\footnotetext{
${ }^{80} \mathrm{C}$. Westerink: wawancara penulis, Bennekom, Nederland, 12 April 2007.

${ }^{81}$ Ton Jansen, wawancara penulis, Bennekom Belanda, 13 Juni 2006.
} 
antara Katekismus Heidelberg dengan Alkitab dan penggunaan katekismus itu secara praktis bagi anak-anak.

Selanjutnya, pada Sidang Sinode Dordercht 1618, tepatnya tanggal 30 November 1618, telah dirumuskan tiga cara untuk memfungsikan Katekismus Heidelberg sebagai materi PAK di lingkungan strategis Kristen, ${ }^{82}$ yaitu: di dalam rumah tangga oleh orang tua sebagai persiapan anak-anak mengikuti pelajaran di sekolah (Belanda: de demestica of huiscatechisatie), di sekolah-sekolah oleh guru-guru (Belanda: de schiolastica of schoolcatechisatie), dan di Gereja oleh para pendeta dan penatua (Belanda: de ecclesiastica of de leerdienst door middle van de catechismusprediking en andere vormen van ambtelijke catechisatie).

Semua itu membuktikan bahwa Katekismus Heidelberg dalam Gereja Calvinisfungsinya sangat kuat dan penting di lingkungan rumah tangga, di sekolah-sekolah, dan dalam persekutuan jemaat (gereja).Tentang penggunaan Katekismus Heidelberg dalam ibadah hari Minggu sore masih dibahas antara lain pada Sidang Klasis Dordrecht di Maasdam tanggal 17 Juli 1619. Salah satu pertanyaan yang dibahas oleh pada sidang Klasis adalah "apakah dalam ibadah hari Minggu sore yang dibacakan pertama-tama teks Alkitab atau hanya bagian tertentu dari Katekismus Heidelberg?". 83 Sidang Klasis memutuskan, bahwa pertama-tama teks Alkitab harus dibacakan dan dijelaskan. ${ }^{84}$

Namun pada kenyataannya, pengunaan Katekismus Heidelberg di

\footnotetext{
${ }^{82} \mathrm{M}$. Golverdingen "De catechismus in het kerkelijk onderwijs" dalam W. Van't Spijker (ed.), Het troostboek...,232.

${ }^{83}$ W. Verboom,'The Heidelbergse Catechismus in Nederland..., 196.

${ }^{84}$ Ibid.
}

sekolah-sekolah melalui peran para guru tidak semulus pengunaanya dalam ibadah di Gereja pada hari Minggu sore. Tidak semua sekolah mewajibkan para gurunya memakai Katekismus itu sebagai bahan pelajaran agama Kristen bagi muridmuridnya. Untuk mengatasi masalah itu maka salah satu Sidang Klasis yang membahas masalah itu adalah Sidang Klasis Roterdam tanggal 24 November 1586. Peserta sidang klasis melihat pentingnya peranan pemerintah untuk menstimulasi pengajaran katekimus Heidelberg di sekolah-sekolah. ${ }^{85}$ Pemerintah dilibatkan untuk membantu gereja dalam program pendidikan di sekolah-sekolah. Hal ini mengingatkan kita pada ajaran Calvin tentang hubungan Gereja dan Negara sebagai hubungan koordinasi dan saling bekerjasama.

Golongan yang jelas-jelas menghindarkan pengajaran Katekismus Heidelberg dari anak-anak mereka adalah anggota Gereja Baptis. Oleh karena itu, maka sidang Klasis Roterdam berikutnyadiberi mandat untuk mengatasi masalah tersebut dan mengurus proses belajar-mengajar yang baik di sekolahsekolah, termasuk penggunaan Katekismus Heidelberg. ${ }^{86}$

Halangan-halangan untuk mefungsikan Katekismus Heidelberg di sekolah dan dalam rumah tangga, muncul juga dari kalangan Remonstran. Mereka yang telah diusir dari Sidang Sinode Dordrecht tahun 1816/1619 menyimpan dendam terhadap peserta sidang sinode waktu itu. Dan mereka melampiaskan dendam mereka dengan tetap menghasut generasi muda untuk tidak menghafalkan jawaban-jawaban Heidelberg. ${ }^{87}$

Katekismus

\footnotetext{
${ }^{85}$ Ibid 197.

${ }^{86}$ Ibid.

${ }^{87}$ Ibid.
} 


\section{Kesimpulan}

Katekismus Heidelberg lahir dari konteks politik dan juga kebutuhan untuk mengakarkan dan menyebarkan pengakuan iman Calvinis di gereja-gereja Eropa khusunya dan dunia pada umumnya. Sejarah perumusan dan penggunaan serta pemahaman atas teologi Katekismus Heidelberg telah membuktikan bahwa Katekismus ini masih sangat layak dijadikan sebagai basis pengajaran PAK, baik di sekolah-sekolah formal maupun di gereja-gereja secara non-formal.

Dari aspek historis, perjalanan dan penyebaran serta penggunaan Katekismus Heidelberg disambut dengan serius oleh gereja, sekolah dan rumah tangga-rumah tangga Kristen. Sambutan itu antara lain dengan adanya pembahasan alot penggunaan katekismus tersebut di persidangan-persidangan gerejawi di Belanda. Baik pada persidangan tertinggi, yakni Sidang Sinode maupun pada tingkat persidangan rendah semisal Sidang-sidang Klasis.

Kemunculan rumusan pokok-pokok ajaran gereja-gereja lokal seakan menutup pintu bagi penggunaan Katekismus Heidelberg masa kini. Akan tetapi, konteks kita saat ini juga tidak luput "konspirasi" politik dan agama seperti konteks munculnya katekismus ini. Karena itulah perlu mendasari setiap perumusan materi pengajaran gereja dan sekolah dengan sabar dan rendah hati membaca dan menggumuli pokok-pokok ajaran yang kontekstual serta mempunyai nilai historis seperti Katekismus Heidelberg. Katekismus Heidelberg adalah salah satu contoh materi PAK yang memperhatikan tiga konteks di mana itu digunakan. Konteks itu adalah rumah tangga, sekolah dan gereja. Ketiga konteks yang selalu mesti diperhatikan dan diindahkan dalam perumusan materi PAK.

\section{Daftar Pustaka}

Buku

Aritonang, Jan S. Berbagai Aliran di Dalam dan Di Sekitar Gereja. Jakarta: BPK Gunung Mulia cet. Ke-7 2005.

Barth, Karl. Inleiding in Den Heidelbergschen Catechismus. Nijker: Enbach N.V., 1938. Learning Jesus Christ Through the Heidelberg Catechism. Grand Rapids: William Eerdmans Publising Company, 1996.

Berkhof, H. Christelijk Geloof. Nijkerk: G.F. Callenbach B.V., 1973.

The Doctrine of the Holy-Spirit. Richmond, Virginia: John Knox Press, 1964.

Darmaputera, Eka. (peny.), Konteks Berteologi Di Indonesia. Jakarta: BPK Gunung Mulia cet. ke-4,2004.

Flooster, H. The Heidelberg Catechism, the History and Origin and History. Grand Rapids, Michigan: Calvin Theological Seminary.1985. Our Only Comfort A Comphensive Commentary on the Heidelberg Catechism,vol. 2. Grand Rapids, Michigan: Faith Alive Christian Resources, 2001.

Gereformeerde Bijbelstiching. Heidelberg Chatechismus. Leerdam: GBS, 1996.

Genderen, J. van. De doop bij Calvijn.Kampen: J.H. Kok, 1983

Heidelberg Catechism volume two. Grand Rapids, Michigan: Faith Alive Christian Resources, 2001. 
Flooster, A. Fred, Our Only Comfort A Compressive Commentary on The Heidelberg Catechism,vol. 2. Grand Rapids, Michigan: Faith Alive Christian Resources, 2001.

Noll, A. Mark. Confessions and Catechism of the Reformation. Leicester: Apollo, 1991.

't Spijker, van (ed.).Het Troostboek van de Kerk-Over de Heidelbergse Catechismus. Houten: der Hertog, 2005.

Williamson, G.I., The Heidelberg Catechism: A study Guide. New Jersey: P \& R Publishing, 1993. Wellem, F.D. Kamus Sejarah Gereja. Jakarta: BPK Gunung Mulia, cet. ke-4, 2006.

Makalah

Hertog, Den.De Kerk ende Middelar (Makalah ceramah kuliah Dogmatika). Apeldoorn: Theologische Universiteit Apeldoorn, September 2005.

Majalah

REC FOCUS vol. 4, No 4, Desember 2004.

\section{Wawancara}

Buitenhuis, Karel. Wawancara penulis, Apeldoorn, Belanda 16 Juli 2006.

Jansen, Ton. Wawancara penulis, Bennekom Belanda, 13 Juni 2006.

Maris, J.W.Wawancara penulis. Apeldoorn, Belanda, 10 November 2006

Nutma, J. Wawancara penulis. Apeldoorn, Belanda 13 April 2007.
Westerink, C. Wawancara penulis, Bennekom, Nederland, 12 April 2007. 